\title{
DNA Methylation Targeting: The DNMT/HMT Crosstalk Challenge
}

\author{
Omar Castillo-Aguilera ${ }^{1}$, Patrick Depreux ${ }^{1}$, Ludovic Halby ${ }^{2}$, Paola B. Arimondo ${ }^{2,3, *}$ and \\ Laurence Goossens ${ }^{1, *}$ \\ 1 Univ. Lille, ICPAL, EA 7365-GRITA—Groupe de Recherche sur les formes Injectables et les Technologies \\ Associées, 3 rue du Pr. Laguesse, F-59000 Lille, France; omar.castilloaguilera@univ-lille2.fr (O.C.-A.); \\ patrick.depreux@univ-lille2.fr (P.D.) \\ 2 FRE3600 Epigenetic Targeting of Cancer, CNRS, 31035 Toulouse, France; ludovic.halby@etac.cnrs.fr \\ 3 Churchill College, Cambridge CB3 0DS, UK \\ * Correspondence: paola.arimondo@etac.cnrs.fr (P.B.A.); laurence.goossens@univ-lille2.fr (L.G.); \\ Tel.: +33-5-61335919 (P.B.A.); +33-3-20-96-47-02 (L.G.)
}

Academic Editors: Gerda Egger and Melanie R. Hassler

Received: 15 November 2016; Accepted: 12 December 2016; Published: 5 January 2017

\begin{abstract}
Chromatin can adopt a decondensed state linked to gene transcription (euchromatin) and a condensed state linked to transcriptional repression (heterochromatin). These states are controlled by epigenetic modulators that are active on either the DNA or the histones and are tightly associated to each other. Methylation of both DNA and histones is involved in either the activation or silencing of genes and their crosstalk. Since DNA/histone methylation patterns are altered in cancers, molecules that target these modifications are interesting therapeutic tools. We present herein a vast panel of DNA methyltransferase inhibitors classified according to their mechanism, as well as selected histone methyltransferase inhibitors sharing a common mode of action.
\end{abstract}

Keywords: DNA methylation; histone methylation; DNMT/HMT crosstalk; DNMT inhibitors; HMT inhibitors

\section{Introduction}

In humans, DNA methylation is a stable epigenetic mark that occurs at the C5 position of cytosines, mainly in a CpG dinucleotide context, but also in non-CpG regions of stem cells [1,2]. More than $50 \%$ of genes are associated with CpG islands in their promoter regions. Generally, low levels or a lack of DNA methylation in the promoter region is correlated with an "on" configuration of chromatin that favors the interaction of DNA with transcription complexes leading to the activation of gene expression. By contrast, methylation of CpG islands in gene promoters is correlated with an "off" configuration of chromatin that leads to gene silencing [3]. DNA methylation can maintain differential gene expression patterns in a tissue-specific and developmental-stage-specific manner. The roles of DNA methylation in gene bodies and other regions started to be characterized in the last years.

Three DNA methyltransferases (DNMTs), DNMT1, DNMT3a and DNMT3b, catalyze the transfer of a methyl group from S-adenosyl-L-methionine (SAM or AdoMet) to the C5 position of cytosine [4]. DNMT1 is responsible for methylating hemimethylated DNA and thus DNA methylation maintenance, whereas DNMT3a and DNMT3b are involved in de novo DNA methylation, but they can also participate in methylation maintenance. DNMT3a has two different isoforms, and DNMT3b has more than 30 isoforms [5,6]. They share common features: a well-conserved C-terminal domain bearing the catalytic activity. It contains motifs I to $X$, responsible for binding the SAM cofactor and the targeted cytosine. They also share an N-terminal domain that contains the ADD (ATRX-DNMT3-DNMT3L) motif and the nucleosome recognition PWWP (Pro-Trp-Trp-Pro) motif. These motifs are responsible for 
the interaction with DNA and with proteins that guide the enzymes to the nucleus, the chromatin and the DNA $[2,7,8]$. DNMT3L does not show a catalytic activity as it lacks the catalytic domain. It works as a coactivator of DNMT3a and DNMT3b, and is involved in the interaction with chromatin actors, improving methyltransferase activity by approximately 1.3 to 4 times [5,9]. It has been demonstrated that DNA methylation is correlated with histone-modification patterns [1,7].

Histones are subject to different post-translational modifications (acetylation, phosphorylation, ubiquitinylation, sumoylation, methylation, etc.) that control the expression of genes [10]. Histone methylation is, like DNA methylation, one of the most studied epigenetic modifications on histones. It can be linked to active transcription (e.g., H3K4me1/me2/m3, HK36me3, H3K79me1/ me2/me3, H4R3me1, H4K20me1) or to gene silencing (e.g., H3K9me2/me3, H3K27me3) [10,11]. Histone methyltransferases (HMT) use, as DNMTs, the SAM cofactor to mono-, di- or tri-methylate lysine residues (thus known as HKMT, histone lysine methyltransferases) or to mono- or di-methylate arginine residues (thus known as PRMT, protein arginine $N$-methyltransferases) of the core or tails of histones [12]. The location and the level of methylation of histones can differently influence DNMT activity. DNA and histone methylation show an important crosstalk [1,13]. For example, the trimethylated residue lysine 36 of the tail of histone 3 (H3K36me3) is linked to gene body DNA methylation and it can be read by the PWWP domain of DNMT3a and DNMT3b to guide DNA methylation. In consequence, a mutation of the PWWP domain or the absence of the epigenetic mark H3K36me3 causes the loss of DNMT-nucleosome interaction, leading to decrease of DNA methylation at pericentromeric regions $[7,14]$. In contrast, at promoter regions, the unmodified H3 can be recognized by DNMT3 via the ADD domain and H3K4 methylation inhibits DNMT3 activity [1].

DNA methylation has an essential role for cell differentiation and development. However, the DNA methylation profile can be altered leading to DNA instability and triggering diseases such as cancer $[12,15,16]$. In tumorigenesis, methylation in the promoter regions of some genes-such as tumor suppressor genes (TSGs) involved in cellular cycle (e.g., cyclin-dependent kinase $(C D K)$ inhibitors, retinoblastoma protein $(R B))$, maintenance of genome integrity (e.g., TP53, breast cancer 1 (BRCA1), $\mathrm{O}^{6}$-methylguanine DNA methyltransferase (06-MGMT), mutL homolog 1 $(h M L H 1))$, apoptosis (e.g., caspase 8, death-associated protein kinase (DAPK), migration process (e.g., E-cadherin (CDH1), metalloproteinase inhibitor 3 (TIMP-3)), and those involved in the response to growth factors (phosphatase and tensin homolog (PTEN), estrogen receptor (ER)) leads to their silencing. At the same time, low levels of gene body methylation participate in genome instability $[17,18]$. Therefore, inhibition of DNA methylation is an interesting approach in cancer treatment [19-22].

\section{Inhibition of DNA Methylation}

\subsection{Cytidine Analogs}

Up to date, several strategies to inhibit DNA methylation have been developed (Figure 1). At present, a suicide substrate of DNMTs is the most advanced approach. 5-Azacytidine or azacitidine (1) and 5-aza-2'-deoxycytidine or decitabine (2) (Figure 2) are indeed the only two DNMT inhibitors (DNMTi) approved by the USA Food and Drug Administration (FDA) and the European Medicines Agency (EMA) for the treatment of acute myeloid leukemia (AML), chronic myelomonocytic leukemia (CMML) and myelodysplastic syndromes (MDS) [17]. These nucleoside analogs, i.e., cytidine analogs, incorporate DNA instead of deoxycytidine, covalently link the enzyme and lead to DNMT degradation $[23,24]$. Although these molecules are particularly active, they have poor chemical and metabolic stability, low specificity-since they incorporate into DNA replacing all cytidines-and they induce several side effects [2]. A more stable and less toxic cytidine analog, zebularine (3), was developed [25,26]. However, its efficacy at very high doses prevented it to enter the clinical trials. Given the success of (1) and (2), prodrugs of these molecules, for instance CP-4200 (4), an elaidic acid ester analog of (1), and SGI-110 (or guadecitabine) (5), a dinucleotide 
decitabine- $p$-deoxyguanosine, were developed to improve the pharmacokinetic profile $[27,28]$. The latter compound is in clinical trials for the treatment of AML, MDS, ovarian and liver cancers (NCT01261312, NCT02901899, NCT01752933).

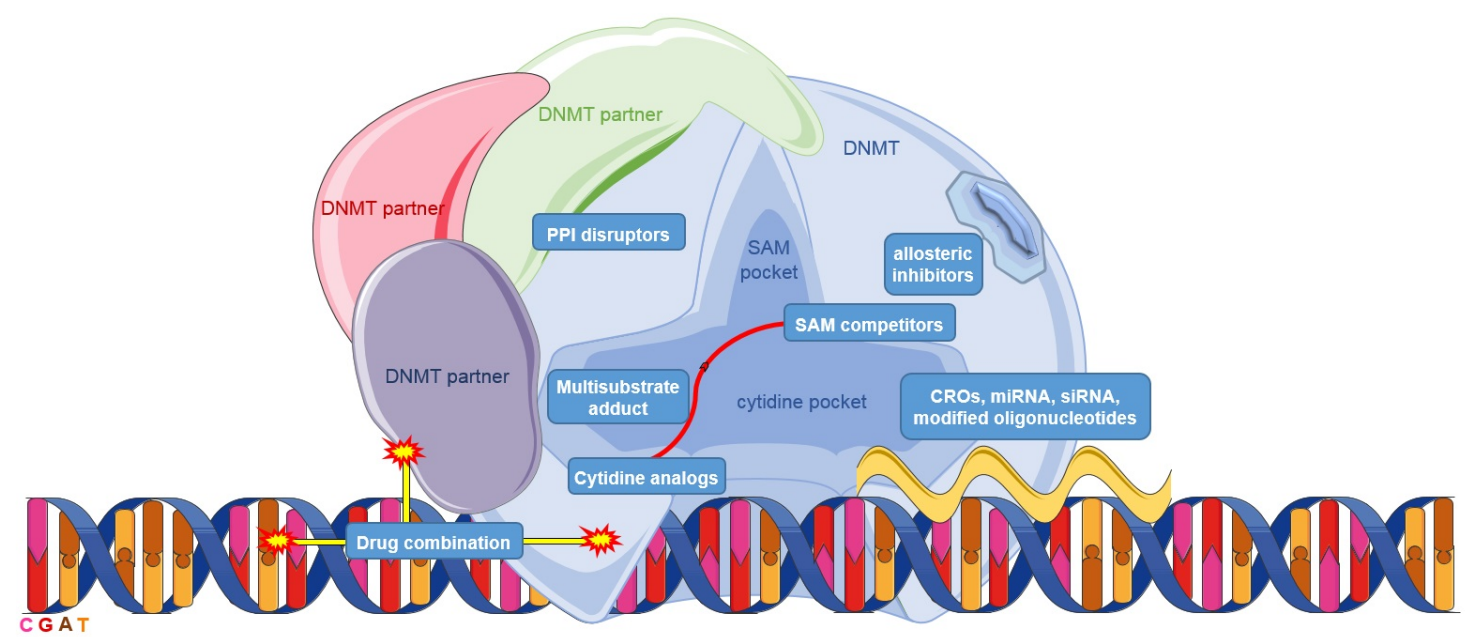

Figure 1. Schematic representation of different DNA methyltransferase (DNMT)-inhibition approaches. DNMT: DNA methyltransferase; PPI: protein-protein interaction; SAM: S-adenosyl-L-methionine; CRO: chimeric RNA oligonucleotides; miRNA: micro RNA; siRNA: small interfering RNA.

$4^{\prime}$-Thio-2'-deoxycytidine (TdCyd) (6) is another cytosine analog in clinical trials for patients with advanced solid tumors (NCT02423057). This compound incorporates into the DNA sequence recognized by the bacterial C5 DNA methyltransferase M.HhaI, leading to DNA methylation inhibition. Furthermore, it depletes DNMT1 in both in vitro and in vivo cancer models $[29,30]$. 5-fluoro-2'-deoxycytidine (FdCyd) (7) has been enrolled in clinical trials for treatment of advanced solid tumors, AML and MS ( NCT00359606, NCT01041443) [31].

Recently, preclinical studies have shown that (1) in combination with 3-deazaneplanocin-A (DZNep) (8) produce a synergistic reactivation of CDKN1A (Cyclin-dependent kinase inhibitor 1A), CDKN1B and FBXO32 (F-Box Protein 32) genes [32,33]. In fact, (8) is an inhibitor of $S$-adenosyl-L-homocysteine (SAH) hydrolase, an enzyme involved in the degradation of SAH (or AdoHcy), the product of the methylation reaction and a natural inhibitor of HMTs and other enzymes. In addition, (1), (2), and (5) are in clinical trials in combination with other drugs (i.e., cytotoxics, monoclonal antibodies or HDACi) to improve the effects and to reduce side effects of monotherapy [34]. To increase their potency, cytidine analogs have been studied in combination with inhibitors of cytidine deaminase (CDA), an enzyme mainly found in the gastrointestinal tract and liver involved in their inactivation by deamination, limiting their bioavailability. These compounds are tetrahydrouridine (THU) (9) or its improved deoxy- and difluorinated derivatives (10 and 11) [35]. Compound E7727 (structure not yet disclosed) is a CDA inhibitor tested in clinical trials (NCT02103478) in a combined formulation with (2) under the name ASTX727.

To overcome the non-specificity of the nucleoside inhibitors, several non-nucleoside molecules have been developed in the past years. Their structures are very heterogeneous, but for all of them their mechanism of action is independent of DNA incorporation. Thus, this class has drawn special attention. 


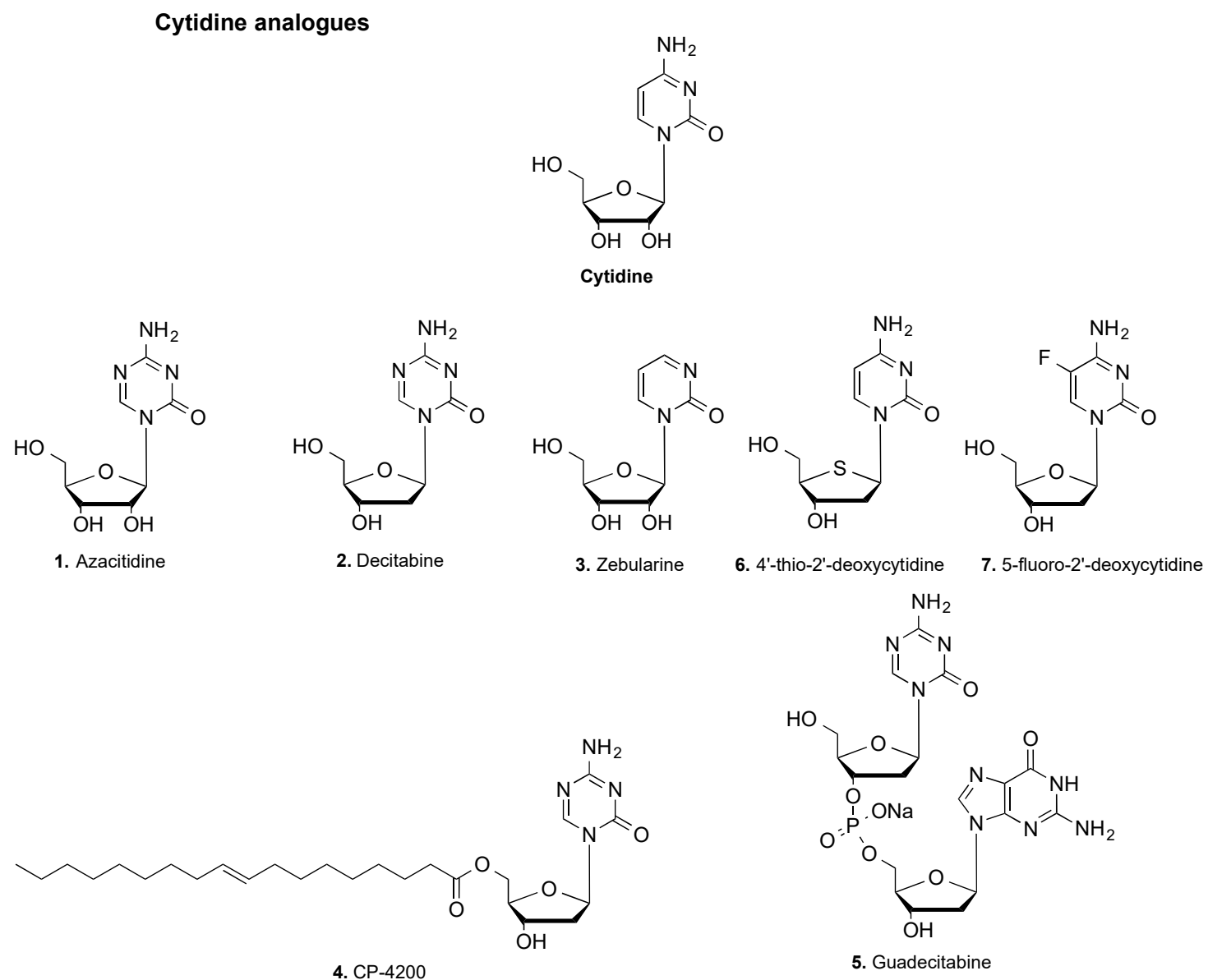

SAH-hydrolase inhibitor

CDA inhibitors<smiles>Nc1nccc2c1ncn2C1C=C(CO)[C@@H](O)[C@H]1O</smiles>

8. 3-deazaneplanocin-A

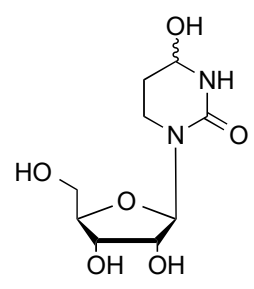

9. Tetrahydrouridine

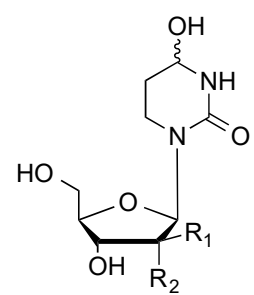

10. $R_{1}=R_{2}=H$

Figure 2. Structures of nucleoside DNMT, S-adenosyl-L-homocysteine (SAH)-hydrolase and cytidine deaminase (CDA) inhibitors.

\subsection{DNA Binders}

Some commercial drugs have been repurposed as they were discovered to show demethylating effects, such as amide procainamide, an antiarrhythmic drug (12) and its ester analog procaine, a local anesthetic (13) (Figure 3, Table 1). These molecules showed affinity for CpG-rich regions of DNA blocking the activity of DNMTs and reactivating some TSGs [36-38]. Other DNA binders tested for DNA methylation inhibition are derivatives of acridine, a heterotricycle known to intercalate into DNA. Particularly, compound 5175328 (14) was able to reactivate methylated silenced genes. Unlike nucleoside analogs (1) and (2) that inhibit DNMT after at least two cell division rounds, as they need to incorporate in DNA, acridine derivatives showed demethylation activity after only one cell 
division round [39]. However, as DNA binders, these compounds can interfere with other DNA enzymes and need to be improved for selectivity.

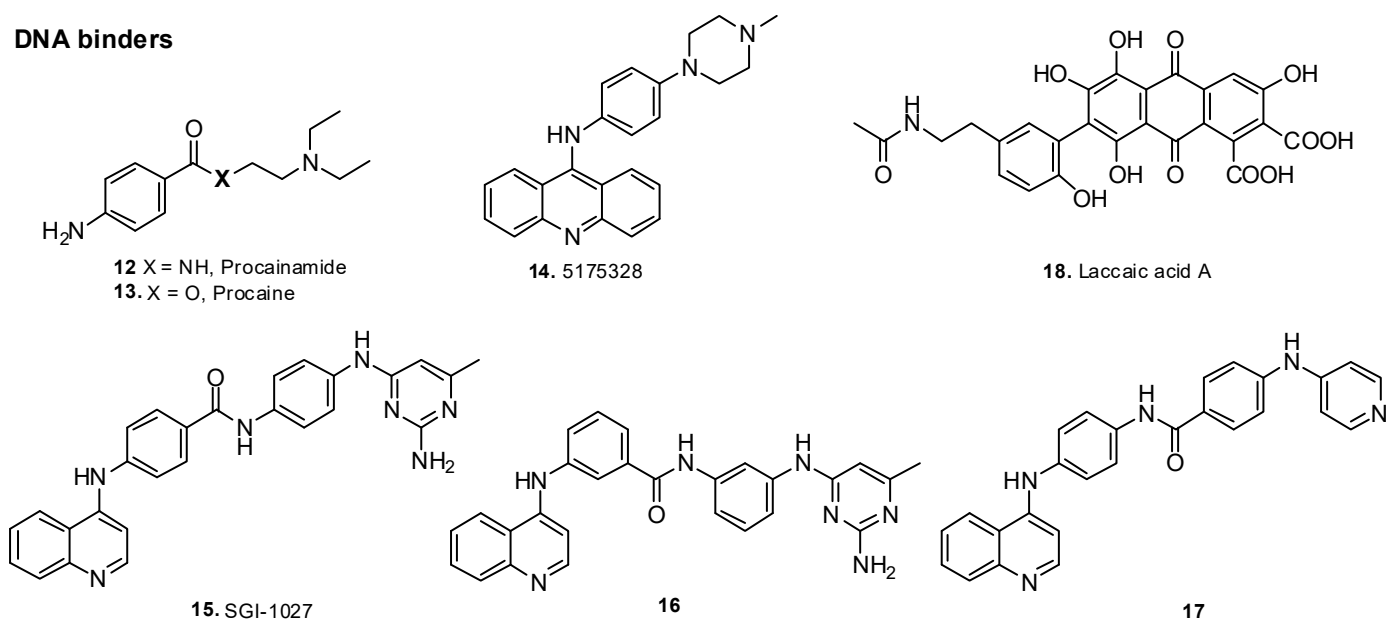

Substrate (DNA / SAM) competitors<smiles>O=C(O)C(Cc1c[nH]c2ccccc12)N1C(=O)c2ccccc2C1=O</smiles>

19. RG-108<smiles>O=[N+]([O-])c1ccc(C2=NCC(CN3CCCC3)O2)cc1</smiles>

20<smiles>O=C(O)C(Cc1c[nH]c2ccccc12)N1C(=O)CCC1=O</smiles>

37. RG-108-1<smiles>CN(C)CC1CC(c2ccc([N+](=O)[O-])cc2)=NO1</smiles>

21<smiles>CCN(CC)CCNC(=O)c1ccc(NN2C(=O)c3ccccc3C2=O)cc1</smiles>

22

Undetermined mechanism<smiles>O=C(O[C@H]1Cc2c(O)cc(O)cc2O[C@H]1c1cc(O)c(O)c(O)c1)c1cc(O)c(O)c(O)c1</smiles>

41. EGCG<smiles>NNc1nncc2ccccc12</smiles>

40. Hydralazine<smiles>C[C@H]1OC(CC(=O)O)CC2=C1C(=O)c1cccc(O)c1C2=O</smiles>

43. Nanaomycin A

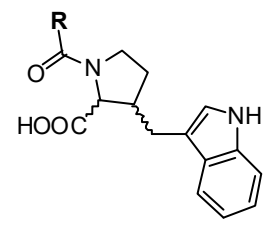

38. $R=$ pheny 39. $R=$ 2-naphthyl<smiles>O=c1c(-c2ccc(O)cc2)coc2cc(O)cc(O)c12</smiles>

42. Genistein

PPIs disruptors/inhibitors<smiles>O=[N+]([O-])c1cc(S(=O)(=O)Nc2ccc(O)c3ccccc23)ccc1Cl</smiles>

44. SW155246<smiles>C/C(NO)=C1\C=NC(=O)NC1=O</smiles>

45. NSC232003

Figure 3. Structures of non-nucleoside DNMT inhibitors.

Compound SGI-1027 (15), a quinolone derivative previously considered as a SAM cofactor competitor, has been recently proven to inhibit DNMT1 and DNMT3a by a DNA-binding mechanism [40,41]. It was also proven to cause DNMT1 proteosomal degradation in colon cancer cells and to demethylate and reactivate TIMP3, MLH1 and P16 promoters in HCT116 cells [41]. 
Due to the positive results of this compound, structure-activity relationship (SAR) studies have been performed to improve the activity of (15). Consequently, derivatives (16) and (17) also showed a DNA-competitive inhibition of DNMT. Compound (16) is the most potent DNMT1 inhibitor among them $[4,42,43]$.

Finally, a natural product, the highly substituted anthraquinone, laccaic acid A (18), was described as a direct, DNA competitive inhibitor of DNMT3a and M.SssI methyltransferase with moderate selectivity for DNMT1. It was also shown to reactivate methylated TSGs [44].

Although DNA competitive or non-competitive binders have shown a particular interest as DNMT inhibitors and TSG reactivators, it is important to highlight that they need CpG-region selectivity at hypermethylated TSGs in cancers in order to not unspecifically affect proteins that recognize and bind DNA.

Table 1. Non-nucleoside DNA methyltransferase inhibitors (DNMTi) and their activity.

\begin{tabular}{|c|c|c|c|c|}
\hline \multirow{2}{*}{ Inhibitor } & \multicolumn{3}{|c|}{$\mathrm{IC}_{50}\left(\text { or } \mathrm{EC}_{50}\right)^{\mathrm{a}}, \mu \mathrm{M}$} & \multirow{2}{*}{ Reference } \\
\hline & DNMT1 & DNMT3a & DNMT3b & \\
\hline 12 (procainamide) & $>500$ & $>300^{a}$ & ND & [38] \\
\hline 15 (SGI-1027) & 6 & 8 & 7.5 & [40] \\
\hline 16 & 9 & $2.8^{b}$ & ND & [4] \\
\hline 17 & (15) & $(0.9)$ & ND & [43] \\
\hline 18 (laccaic acid A) & 19 & 50 & ND & [44] \\
\hline 19 (RG-108) & 390 & $315^{b}$ & ND & {$[45,46]$} \\
\hline 37 (RG108-1) & 20 & ND & ND & [47] \\
\hline $\mathbf{3 8 a}(2 S, 3 R)$ & 98 & ND & ND & \multirow{2}{*}{ [46] } \\
\hline $\mathbf{3 8 b}(2 R, 3 S)$ & 73 & ND & ND & \\
\hline $39 \mathbf{a}(2 S, 3 R)$ & 128 & ND & ND & \multirow{2}{*}{ [46] } \\
\hline $39 \mathbf{b}(2 R, 3 S)$ & 50 & ND & ND & \\
\hline 21 & 150 & ND & ND & [48] \\
\hline 22 & 4 & $21^{\mathrm{b}}$ & ND & [45] \\
\hline 41 (EGCG) & 0.5 & ND & ND & [49] \\
\hline 42 (genistein) & 30 & $>100$ & ND & [51] \\
\hline 43 (nanaomycin $\mathrm{A}$ ) & inactive & ND & 0.5 & [52] \\
\hline 44 (SW155246) & 1.2 & 38 & ND & [53] \\
\hline
\end{tabular}

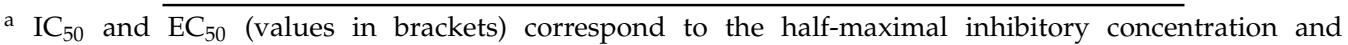
the half-maximal effective concentration, respectively. Both are calculated from enzymatic assays. Assays are based either on the incorporation of radioactive methyl groups, or on methyl-sensitive restriction enzymes, or on the use of antibodies. ${ }^{b}$ DNMT3a/3L complex. ND: Not Described.

\subsection{Oligonucleotides}

Besides DNA binders, short RNA molecules (4-8 nucleotides) are theoretically long enough to be accommodated in the catalytic pocket of DNMTs and to be effective, competitive inhibitors. With this aim, chimeric RNA oligonucleotides (CROs) have been developed; they specifically target genes and reduce DNMT catalytic activity. The CROs can bind a carrier (e.g., lipopolysaccharide, liposome, nanoparticles) in a covalent or non-covalent way that favors its transport into a particular cell type. The CROs are formed by 15-30 nucleotides with one or two modified nucleotides. They are at least $80 \%$ complementary to a portion of an extracoding RNA of a gene. Once they bind, the complex form binds DNMT and prevents DNA methylation of this gene [20,54]. Other small RNAs have also been studied as DNA competitive inhibitors of DNMTs. Unlike the CROs previously described, New England Biolabs Inc. (Ipswich, Massachusetts, USA) identified small RNA molecules (Table 2, entries 1-3) that inhibit DNMT activity globally. Their complementarity to human genes is less than $80 \%[20,55]$. Another type of oligonucleotide includes at least one modified CpG dinucleotide that functions to 
trap the DNMTs. On one strand, the cytosine of CpG is replaced by a cytosine analog -(1), (2), (3) of Figure 2, for instance, and, on the opposite strand, the cytosine remains unmodified or substituted by a methylated cytosine (to create a hemimethylated target for DNMTs). These oligonucleotides are configured to form a double-stranded hairpin when annealed (Table 2, entries 4-6) [20,56].

Table 2. Examples of oligonucleotide-based inhibitors.

\begin{tabular}{|c|c|c|c|c|c|c|}
\hline \multirow{2}{*}{ Entry } & \multirow{2}{*}{ Inhibitor } & \multirow{2}{*}{ Sequence ( $5^{\prime}$ to $\left.3^{\prime}\right)$} & \multicolumn{3}{|c|}{$\mathrm{IC}_{50}\left(\text { or } K_{i}\right)^{\mathrm{a}}, \mu \mathrm{M}$} & \multirow{2}{*}{ Reference } \\
\hline & & & (DNMT1) & (DNMT3a) & (DNMT3b) & \\
\hline 1 & $\operatorname{asCEBP} \alpha-2$ & GCCAGUGGCGAGGGGCGGCGCGG & $(0.4341)$ & ND & ND & [55] \\
\hline 2 & asCEBP $\alpha-2 \mathrm{HPE}$ & GACAGUGGAGAGGGGCGGAGCGG & $(0.1352)$ & ND & ND & [55] \\
\hline 3 & miR-155-5p & UUAAUGCUAAUCGUGAUAGGGGU & $(0.02788)$ & ND & ND & [55] \\
\hline 4 & MTC-423 & $\begin{array}{l}\text { CCTATGCGATCGAGTTTTCT[z]GAT[z]GCATAGG } \\
\mathrm{z}=\text { zebularine }\end{array}$ & 0.363 & 1.60 & 17.5 & [56] \\
\hline 5 & MTC-427 & $\begin{array}{l}\text { CCTATG[M]GAT[M]GAGTTTTCT[z]GAT[z]GCATAGG' } \\
\mathrm{M}=\text { methylcytosine; } \mathrm{z} \text { = zebularine }\end{array}$ & 0.295 & 1.52 & 6.20 & [56] \\
\hline 6 & MTC-433 & $\begin{array}{l}\text { CCTATG[M]GAT[M]GAGTTTTCT[dz]GAT[dz]GCATAGG } \\
\mathrm{M}=\text { 5-methylcytosine; } \mathrm{dz} \text { = deoxyzebularine }\end{array}$ & 0.00422 & $N D$ & $N D$ & [56] \\
\hline 7 & MG98 & TTCATGTCAGCCAAGGCCAC & ND & ND & ND & {$[57,58]$} \\
\hline 8 & $\mathrm{miR} 29 \mathrm{~b}$ & UAGCACCAUUUGAAAUCAGUGUU & ND & ND & ND & [59] \\
\hline
\end{tabular}

Other oligonucleotides, named epi-miRNAs, were developed to directly inhibit the transcription of DNMTs [60]. These micro RNAs are complementary to the $3^{\prime}$-untranslated region of the DNMT1 mRNA and lead to blocking DNMT gene transcription. Several mi-RNAs that directly target DNMT mRNA have been developed. For instance, oligonucleotide MG98 (Table 2, entry 7), a 20-nucleotide-antisense sequence with phosphorothioate linkages and 2'-O-methyl modifications, has shown interesting preclinical results proving inhibition of DNMT activity, re-expression of TSGs and tumor growth inhibition. Unfortunately, the clinical trials failed due to high toxicity and poor efficacy $[57,58,61-64]$. In order to improve the activity and to reduce toxicity, this oligonucleotide is the subject of further studies in combination with other agents [58]. Another example of epi-miRNA is the oligonucleotide miR29b (Table 2, entry 8) that targets DNMT1, DNMT3a and DNMT3b, leading to a decrease of DNA methylation levels and the re-expression of TSGs [59,65-67].

In parallel, small interfering RNAs (siRNAs), short, non-coding double-stranded RNAs, have been designed to directly target the genes that code for DNMT1, DNMT3a and DNMT3b. After DNMT degradation, they promote the expression of CTA (cancer/testis antigen), regulated by DNMTs that may be beneficial for immunotherapy of tumors $[68,69]$. However, their poor bioavailability and stability in physiological conditions limits their development in clinics.

\subsection{S-adenosyl-l-methionine Cofactor Competitors}

A very interesting DNMT inhibition approach is the targeting of SAM cofactor binding site in the enzyme. Several molecules have been described to be SAM competitors showing DNMT inhibition and leading to TSG reactivation. The first one was phthalimido-L-tryptophan RG-108 (19), identified as a hit in a virtual screening and validated as an inhibitor of the DNMT activity in vitro and in cancer cells. It was shown to reactivate TSGs, such as P16, TIMP3 and SFRP1, in the colon cancer cell line HCT116 by promoter demethylation [70,71].

Chemical modifications of the DNA ligands (12/13) led to constricted oxazoline and izoxazoline derivatives (20) and (21) [48,72]. Unlike (12/13), these derivatives resulted as SAM competitors. Since they showed in vitro activity over DNMT1, inhibition of HCT116 cell proliferation and weak global DNA demethylation in cancer cells, they represent lead molecules to be further optimized.

Conjugates of (12) (a DNA binder) with (19) (a SAM competitor) have been reported (22) [45]. As expected, procainamide concentrated the conjugate at CpG-rich regions, while the RG-108 part 
was well positioned to inhibit the enzyme. Thus this strategy resulted in inhibitors up to 50 times more active than the parent compounds. They were also found to be selective for DNMTs versus mammalian histone G9a methyltransferase.

Development of SAM competitors to inhibit DNMT represents a promising strategy. Nevertheless, since other methyltransferases use SAM as their cofactor, such as histone methyltransferases, DNMT specificity is a challenge.

\section{Inhibition of Histone Methylation}

HMTs are a large family of protein methyltransferases (over 50 of them) that methylate lysine or arginine residues present in the core or in the tails of histones. Due to the direct or indirect role of some HMTs in tumorigenesis, HMT inhibitors (HMTi) have been developed [21,73]. Development of SAM competitors remains one of the most advanced approaches.

\subsection{Histone Lysine Methyltransferases}

All HKMT contain the conserved protein-protein domain SET (Su(var)3-9, Enhancer of Zeste, Trithorax), except for disruptor of telomeric silencing 1-like (DOT1L). Among the HKMT family, G9a and G9a-like protein (GLP) are two HKMTs that catalyze H3K9me1 and H3K9me2, and with Suv39H1, Suv39H2, and SETDB1, complete the SET-containing SUV39 protein family responsible for H3K9 methylation, an epigenetic modification found to be dependent on DNA methylation in human cancer cells [74-76]. G9a and GLP apparently form a functional heteromeric complex with in vivo H3K9 methyltransferase activity [76-79]. Furthermore, this complex was shown to promote tumor growth, affect cell cycle or metabolism pathways [80]. Several inhibitors have been developed, such as the substrate-competitive compound BIX-01294 (23) and the SAM-competitor compound BIX-01338 (24), both discovered in the same HTS (Figure 4, Table 3) [81]. To improve their selectivity and to decrease their toxicity, other compounds were synthetized [82], such as compound BRD9539 (25) and its methyl-ester analog BRD4770 (26), found to be useful as probes of G9a [83]. Compound (25) seems to be the active form of (26). The latter was active in cell-based assays and it was shown to reduce cellular levels of H3K9 methylation (without inducing apoptosis), to induce senescence, and to inhibit proliferation in the pancreatic cancer cell line PANC-1 [83]. In addition, other pharmacomodulations of (23) led to a quinazoline derivative that shifts G9a/GLP inhibition to DNMT3a inhibition, suggesting the interest in studying the DNMT/HMT specificity of DNMT inhibitors [84]. In mammals, DNA and H3K9 methylation are strongly associated. Indeed, DNA methylation is lost in G9a or GLP-mutated cells. G9a and GLP can recruit DNMT3a and DNMT3b directly or indirectly through the chromodomain protein M-phase phosphoprotein 8 (MPP8), leading to de novo DNA methylation [75,85-88].

Importantly, it was shown that it was possible to find selective SAM-mimetic molecules to inhibit HMTs potently enough to enter clinical trials [12]. For instance, EPZ6438 (tazemetostat) (27) [89], GSK126 (28) [90] and CPI-1205 [91], SAM-competitive inhibitors of Enhancer of Homolog Zeste 2 (EZH2), are currently in phase I/II clinical trials. Compound EPZ5676 (pinometostat) (29) [92-94], a SAM-competitive DOT1L inhibitor, has just completed phase I clinical trials (last updated August 2016), its clinical development was stopped due to the lack of efficacy in monotherapy.

$\mathrm{EZH} 2$ and its homolog EZH1 are part of the core of the polycomb repressive complex 2 (PRC2). PRC1 and -2 are both involved in transcription repression of specific genes. EZH2/EZH1 are responsible for $\mathrm{H} 3 \mathrm{~K} 27$ methylation, which maintains transcriptional silencing. Ectopic expression of EZH2 is considered as a biomarker of metastasis and poor-prognosis tumors. EZH2 and DNMT have been suggested to have a cross-mechanism of epigenetic silencing that contributes to transcriptional repression of specific genes in cancer cells [95-99]. Hence, several inhibitors have been developed to specifically target EZH2. Compound CPI-169 (30) inhibits the catalytic activity of PRC2, decreases H3K27me3, and triggers cell cycle arrest and apoptosis in different cell lines. In combination with other drugs, it caused tumor regression in a KARPAS-422 model [91,100]. 
To date, three compounds are in clinical trials: (27) for B-cell and follicular lymphomas, sarcoma, mesothelioma and advanced solid tumor treatment (NCT01897571, NCT02601950, NCT02601937, NCT02860286); (28) for B-cell, follicular, and other non-Hodgkin's lymphomas, solid tumors, and multiple myeloma (NCT02082977); and CPI-1205 for B-cell lymphoma treatment (NCT02395601). Compounds (27) and (28) contain a 2-pyridone moiety linked to a benzamide or indole-amide core, and they have a SAM-competitive mechanism.

\section{G9a/GLP inhibitors}

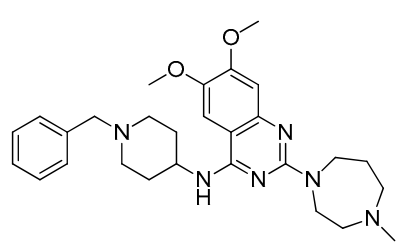

23. BIX-01294

\section{EZH2 inhibitors}<smiles>CCN(c1cc(-c2ccc(CN3CCOCC3)cc2)cc(C(=O)NCc2c(C)cc(C)[nH]c2=O)c1C)C1CCOCC1</smiles>

27. EPZ6438, tazemetostat
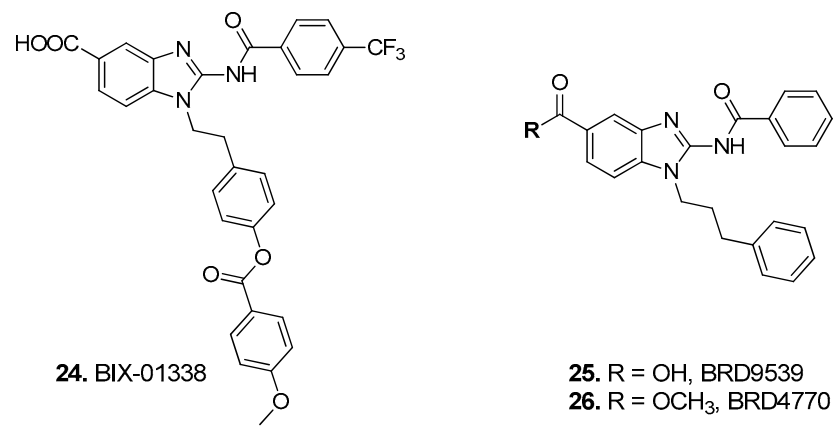

25. $\mathrm{R}=\mathrm{OH}, \mathrm{BRD} 9539$

26. $\mathrm{R}=\mathrm{OCH}_{3}, \mathrm{BRD} 4770$

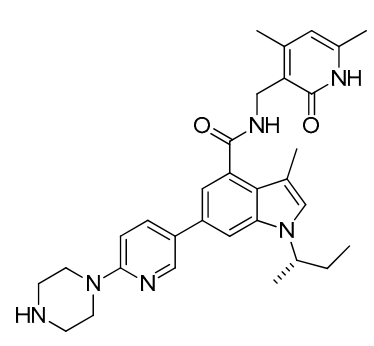

28. GSK126

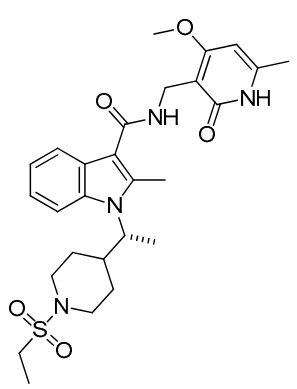

30. $\mathrm{CPI}-169$

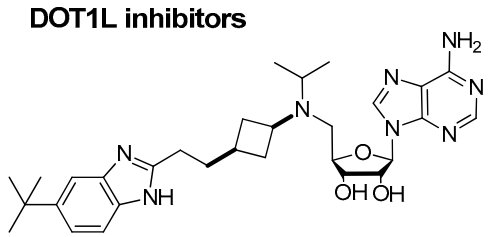

29. EPZ5676, pinometostat

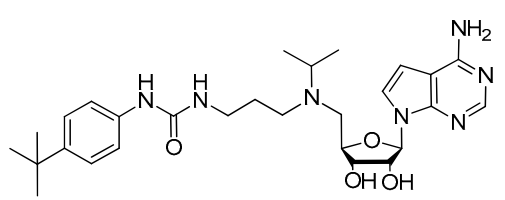

31. EPZ004777<smiles>CNc1ccnc(Nc2ccc3sc(Cl)c(-c4cc(C5C(=O)N(C)CN=C5C)cnc4Cl)c3c2)n1</smiles>

32<smiles></smiles>

33<smiles>Nc1ncnc2ccc(N(CC#CC(O)c3nccn3CCO)c3c(Cl)cccc3Cl)cc12</smiles>

34

\section{PRMT inhibitors}<smiles>O=c1oc2c(O)c(O)cc3c(=O)oc4c(O)c(O)cc1c4c23</smiles>

35. ellagic acid, TBBD

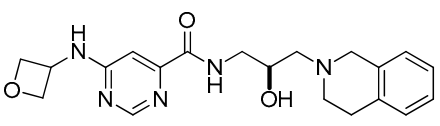

36. GSK3235025 (before EPZ015666)

Figure 4. Structures of selected histone methyltransferases (HMT) inhibitors. G9a: euchromatic histone-lysine N-methyltransferase 2; GLP: G9a-like protein; EZH2: enhancer of zeste homolog 2; DOT1L: disruptor of telomeric silencing 1-like; PRMT: protein arginine $N$-methyltransferase. 
Compound (29) is the result of pharmacomodulations mimicking SAH. The adenosine derivative (29) and its phenylurea analog (31) (EPZ004777) [101] showed very good inhibition and specificity for DOT1L, reduced leukemia-relevant gene expression and induced differentiation of MLL (mixed-lineage leukemia) leukemia cells. DOT1L is the only non-SET domain HKMT and it is the only enzyme responsible for mono-, di- and trimethylation of $\mathrm{H} 3 \mathrm{~K} 79$, leading to transcriptional activation of certain oncogenes [102-107]. It is mainly involved in myeloid lymphoid leukemia with MLL rearrangements by favoring transcription of HOX (subset of homeotic genes) and MEIS (Meis homeobox 1) genes involved in acute leukemia development $[105,106,108]$. Therefore, medicinal chemistry efforts for DOT1L inhibition have led to the first HMTi in clinics, compound (29) that completed phase I clinical trials for leukemia treatment and myelodysplastic syndromes (NCT02141828, NCT01684150). In order to improve its pharmacokinetic properties, other SAH-mimetics were synthesized [109], non-ribose-containing analogs have been developed [110] and non-nucleoside derivatives have been obtained from a fragment-based approach. Novel structures have been disclosed such as (32), (33) and (34) that also show a SAM-competitive mechanism to inhibit DOT1L [111,112]. Other derivatives with $\mathrm{IC}_{50}$ in the micromolar ranges have been identified by means of docking screenings and in silico studies as well $[113,114]$.

Table 3. HMT inhibitors and their activity.

\begin{tabular}{|c|c|c|c|c|c|c|c|}
\hline \multirow{2}{*}{ Inhibitor } & \multicolumn{6}{|c|}{$\mathrm{IC}_{50}{ }^{\mathrm{a}}, \mu \mathrm{M}$} & \multirow{2}{*}{ Reference } \\
\hline & Suv39H1 & G9a & EZH2 & DOT1L & CARM1 (PRMT4) & PRMT5 & \\
\hline 23 (BIX-01294) & $>10$ & 2.7 & ND & ND & ND & ND & [81] \\
\hline 24 (BIX-01338) & 1.1 & 4.7 & ND & ND & ND & ND & [81] \\
\hline $25($ BRD9539) & ND & 6.3 & ND & ND & ND & ND & [83] \\
\hline 27 (EPZ6438, tazemetostat, E7438) & ND & ND & 0.012 & $>100$ & $>100$ & $>100$ & [115] \\
\hline 28 (GSK2816126, GSK126) & $>100$ & $>100$ & 0.009 & $>100$ & $>100$ & $>100$ & [90] \\
\hline 29 (EPZ5676, pinometostat) & ND & ND & ND & 0.0008 & $>50$ & 30 & [116] \\
\hline $30($ CPI-169) & ND & ND & $<0.001^{b}$ & ND & ND & ND & [91] \\
\hline 31 (EPZ004777) & ND & ND & $>50^{b}$ & 0.0004 & $>50$ & 0.521 & [101] \\
\hline 32 & ND & ND & ND & 0.0014 & ND & ND & [111] \\
\hline 33 & ND & ND & ND & 0.0004 & ND & ND & [111] \\
\hline 34 & ND & ND & ND & 0.014 & ND & ND & [112] \\
\hline 35 (ellagic acid, TBBD) & ND & ND & ND & ND & 25 & ND & [117] \\
\hline 36 (GSK3235025, EPZ015666) & ND & ND & ND & ND & ND & 0.022 & [118] \\
\hline
\end{tabular}

${ }^{a} \mathrm{IC}_{50}$ corresponds to the half-maximal inhibitory concentration and they are calculated from enzymatic assays based on the use of radioactive AdoMet or on the use of antibodies. Suv39H1: Suppressor of variegation 3-9 homolog 1; G9a: euchromatic histone-lysine N-methyltransferase 2; EZH2: enhancer of zeste homolog 2; CARM1: coactivator-associated arginine methyltransferase.

\subsection{Protein Arginine N-Methyltransferases}

The protein arginine methyltransferases (PRMT) are a family of 11 enzymes that catalyze monoor dimethylation of arginine residues on histones. As HMTs, they use SAM as methyl donor. Up to date, PRMT inhibitors (PRMTi) are still limited to preclinical studies. Ellagic acid (TBBD) (35) and pyrazole-containing derivatives have been elucidated as inhibitors of coactivator-associated arginine methyltransferase (CARM1, also known as PRMT4), responsible for catalyzing H3R17me2 and H3R26me2, modifying non-histone proteins (e.g., p300/CBP (CREB-binding protein) and SRC-3 (Steroid receptor coactivator-3)), co-activating several transcription factors (e.g., steroid receptors) and being involved in prostate and breast cancer progression [117,119-121]. GSK3235025 (previously known as EPZ015666) (36) was proven to be a potent, selective inhibitor of PRMT5, a PRMT responsible for catalyzing H4R3me2 and H3R8me2, being active on non-histone substrates (e.g., p53, programmed cell death 4 (PDCD4)) and acting as a transcriptional repressor. PRMT5 deregulation has been linked to tumorigenesis [122,123] and (36) showed efficacy in in vitro and in vivo models of mantle cell lymphoma (MCL) [118,124]. Compound (36) was used as a probe for the enzyme study, while the improved compound GSK3326595 (previously known as EPZ015938), has recently entered dose escalation phase of clinical trials (NCT02783300) for the treatment of solid tumors and 
non-Hodgkin's lymphoma [125]. The chemical structure of the latter compound has not yet been disclosed. CARM1-specific and PRMT5-specific inhibitors bind the substrate-binding pocket, rather than competing with the SAM cofactor. However, interestingly, the binding of SAM is needed for the activity of (36).

\section{DNA Methyltransferase-Isoform Selectivity}

An interesting but controversial issue is the selectivity towards DNMT isoforms. Selective compounds will allow studying the role of each isoform in different cancers and identifying the best DNMT isoform for target in cancer cells [17,126,127]. The studies on the HMT inhibitors and on the kinase inhibitors have illustrated that it is possible to design specific cofactor-mimicking inhibitors. Therefore, this might also be possible for DNMTs [128]. Although the catalytic pockets of DNMTs are well conserved, some amino acid residues are different. For instance, Trp1173 in DNMT1 is replaced by Cys662 in DNMT3a, Asn1580 by Arg887, and Val582 by Trp889. Thus, design of selective DNMT inhibitors could be achieved [17]. Also, it has been observed that the SAM cofactor can adopt a different conformation in its binding pocket according to the type of methyltransferase, which can provide a molecular basis for ligand-based design and pharmacophore-based screening to develop SAM-competitive inhibitors [129]. It is noteworthy that the catalytic pockets are dynamic, and inhibitors can induce conformational changes, as is the case for compounds (29) and (31) that bind in the the SAM cofactor binding site of DOT1L $[93,130]$, thereby inducing a conformational change that leads to a gain of selectivity.

\section{Inhibition of DNA Methylation: Other Approaches}

\subsection{Allosteric and Bisubstrate Approaches}

As other enzymes, DNMTs should have allosteric sites that can be targeted to regulate their activity. No compounds have been identified with this mechanism of action.

Since the methyltransferases have two substrates, the cofactor and the DNA, a multisubstrate approach can be considered.

Compounds such as maleimide derivatives (37) (also known as RG108-1), (38) and (39), developed from the SAM-competitive DNMT inhibitor (19), were shown to fit not only in the SAM cofactor pocket, but also in the cytidine binding pocket as suggested by an in silico model (Figure 3, Table 1) [46,47]. Some flavones and flavanones have been identified to inhibit DNMT3a/3L complex in lower micromolar ranges by a mixed mechanism according to docking studies [51].

The hybrids of (12) with (19) were designed considering this combined strategy, and (22) was elucidated with greater inhibition activity compared to the parent compounds [45].

\subsection{Repositioned Drugs and Natural Products}

As evoked above, certain commercial drugs showed demethylating effects. This was also the case of hydralazine (40), an antihypertensive drug that has led to reactivation of TSGs without causing a global genomic demethylation in cells [36,131]. The mechanism of action of hydrazaline is still a controversial issue as some groups claimed that it binds to the catalytic site of DNMT, while others reported that it reduces DNMT1 and DNMT3a expression via the extracellular signal-regulated kinase (ERK) pathway inhibition [132,133]. This drug is in different phases of clinical trials as an anticancer drug, and registered in Mexico in combination with an HDAC inhibitor, i.e., magnesium valproate, for MDS treatment [134,135].

In addition to repositioned drugs, several natural products have shown demethylating effects. For example, the natural polyphenol (-)-epigallocatechin 3-gallate (EGCG) (41) is proven to decrease DNA methylation and to reactivate the TSGs P16, P21, MGMT, RAR 32 (retinoic acid receptor $\beta 2)$ in cancer cell lines [49,50,136,137]. However, its action mechanism has not been elucidated. It has been hypothesized that SAH production by the SAM-mediated methylation 
of EGCG, catalyzed by catechol-O-methyltransferase (COMT), leads to a negative feedback on SAM-dependent methyltransferases, such as DNMT, although in silico studies have suggested that (41) binds the catalytic site of the enzyme, leading to a direct DNMT inhibition $[137,138]$ and DNMT3a degradation [139]. Most recently, the antiproliferative effect of (41) has been studied in the presence of COMT inhibitors (i.e., entacapone and tolcapone) supporting the idea that it is active by different pathways and targets [140]. As flavonoids are multi-target compounds [141], it is difficult to consider (41) or genistein (42), the main soybean constituent, as potential therapeutic tools. Nonetheless, synthetic flavonoids have been identified to show specific DNMT inhibition activity [51].

The natural quinone antibiotic nanaomycin A (43) [52,142] and a sulfonamide derivative identified in an HTS, SW155246 (44) $[53,143]$, have garnered attention as they have shown DNMT inhibition activity and weak but considerable demethylation of promoter regions of specific genes, leading to TSG reactivation. Compound (43) seems to have other targets and its demethylation activity needs further validation.

Even if in silico studies have shown that the compounds cited in this section interact with the catalytic site of DNMT, further biological studies are needed to determine their real mechanism.

\subsection{Protein-Protein Disruptors}

Another approach to inhibit DNMT activity is to target the protein-protein interactions (PPI) needed for the interaction of the enzyme with its partners [8,20]. Earlier in this paper, two interactions were discussed: H3K36me3 recognized by the PWWP domain of DNMTs, and unmodified H3 recognized by the ADD domain of DNMT3a $[1,7,14]$. In the first case, the PWWP domain of DNMTs can be directly targeted, or the methylation of H3K36 can also be inhibited to indirectly affect DNA methylation. In fact, $\mathrm{H} 3 \mathrm{~K} 36$ has been proven to have an important role in tumorigenesis; several H3K36 methyltransferases and fusion partners of this modification have been found to be dysregulated or overexpressed in some cancers (i.e., nuclear SET domain containing proteins, ASH1 like histone lysine methyltransferase, SET and MYND domain containing 2 protein (SMYD2)) [144]. In the second case, the ADD domain of the enzyme can be targeted to disrupt the interaction with the nucleosome. It is known that methylated H3K4 disrupts the ADD-H3 interaction [145]. Also, another potential interacting site is between ubiquitin like with PHD and ring finger domains 1 protein (UHRF1) and DNMT1. UHRF1 is an accessory protein responsible for the interaction of the enzyme with the hemimethylated DNA [146]. This protein has different domains that bind to other marks, such as the tandem Tudor domain that binds H3K9me2/3 [147], and an ADD-like domain that binds the histone H3 tail [148]—an example of the DNA/histone methylation crosstalk. Although several PPIs have been described, no validated DNMT inhibitors have been identified following this strategy. Up to date, some studies have given interesting results, such as peptides that inhibit the DNMT1/CFP1 interaction, important for the enzyme functionality [149]. Most recently, a uracil derivative NSC232003 (45) has been found to inhibit in vitro DNA methylation by disrupting the DNMT1/UHRF1 interaction at a cellular level [150]. In addition, a clustered regularly interspaced palindromic repeat clustered regularly interspaced short palindromic repeats (CRISPR)/Cas9 system was proven to affect the DNA methylation pattern, and it may represent a novel profitable approach [151]. Disruption of PPIs in DNMT-involving complexes represents a very specific and targeted cancer treatment approach [8].

\subsection{Multitarget Inhibitors}

Given the crosstalk of DNA and histone methylation, a multitarget approach is a profitable challenge to develop new molecules with enhanced anticancer activity. As evoked above, the combination of DNMTi 1 and the SAH hydrolase inhibitor (8) represents this emerging approach [33]. Furthermore, keeping in mind that SAM is the cofactor of both DNMT and HMTs, dual inhibitors, i.e., agents with a double effect, might also represent an interesting anticancer approach [84]. 


\section{Conclusions}

The ongoing studies of DNA methylation, including its crosstalk with histone methylation and the protein complexes involved, have pointed out its role in cancers. Therefore, DNMTs are validated therapeutic targets, as proven by two commercial drugs ((1) and (2)) targeting DNA methylation. Clinical investigation on epigenetic agents that show only weak or no clinical activity should not be abandoned as some of these agents may produce a potent enhancement of the clinical activity of other epigenetic agents. Thus, clinical trials of these combinations should be investigated, especially the combinations that are supported by found preclinical data. In fact, clinical studies are ongoing using these epi-drugs in combination with cytotoxic agents, immune therapy or with other epi-drugs (histone deacetylase inhibitors, HDACi) (Figure 5) [152]. Several technological efforts have been used to discover new, less toxic DNMT inhibitors: high-throughput screening (HTS) of different rich libraries, docking-based virtual screenings, fragment-based design, molecular modelling from the enzyme crystal structures, optimization of current DNMT inhibitors and rational design of new ones. Despite the efforts to develop new DNMT inhibitors, this task remains a challenge, not only to have new drugs, but also to develop selective probes that contribute to the better understanding of the DNA methylation. The very promising results with molecules reprogramming cancer cells give hope to pursuing this task.

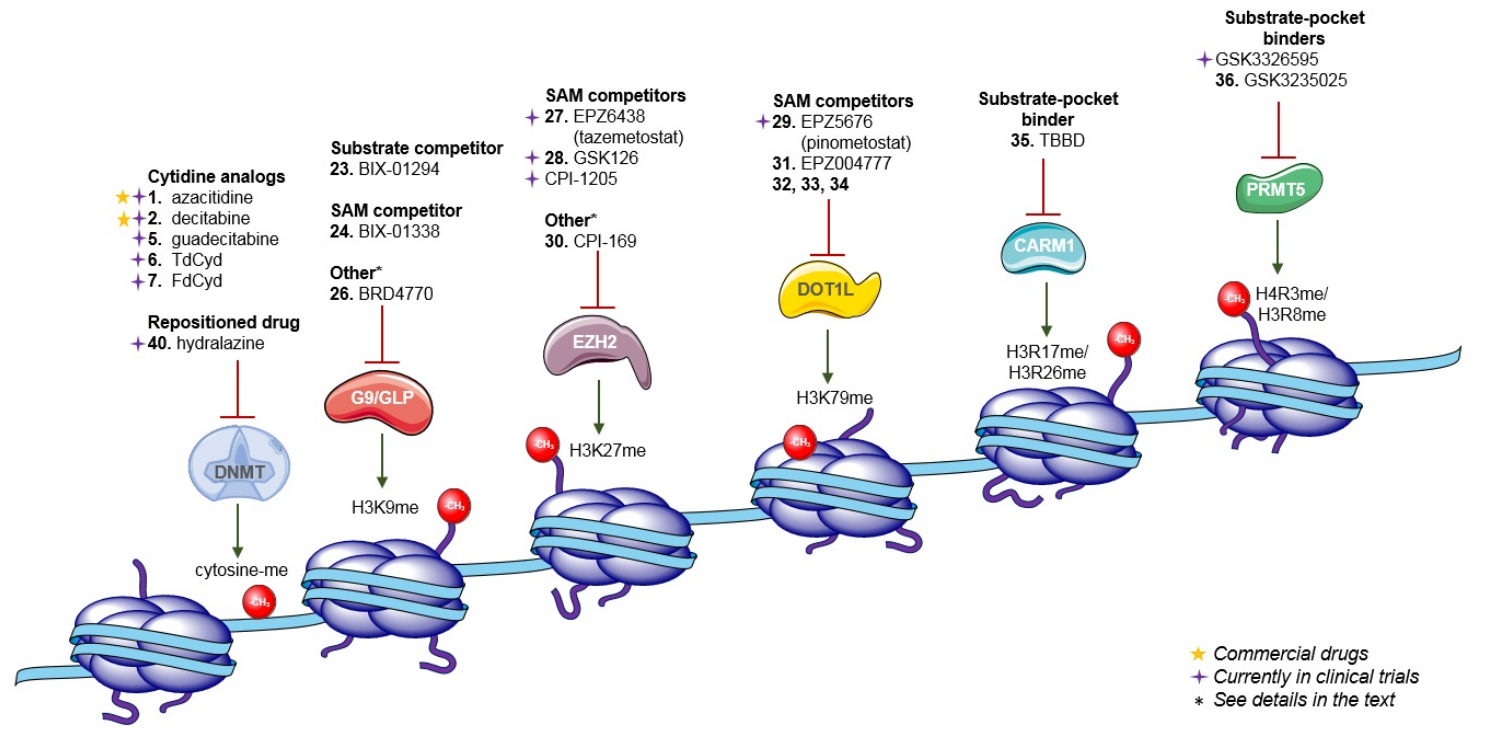

Figure 5. Summary of DNMT and HMT inhibitors. The molecules labeled with a star are commercial and those marked with a cross are currently in clinical trials.

Acknowledgments: This work was supported by Centre National de la Recherche Scientifique (CNRS) and PlanCancer 2014 (AAP Epigénétique et Cancer) (to P.B.A.), and by a Ph.D. fellowship by the Ecole Doctorale Biologie Santé de Lille and National Council of Science and Technology (CONACYT, Mexico) (to O.C.A.).

Conflicts of Interest: The authors state no conflict of interest.

\section{References}

1. Du, J.; Johnson, L.M.; Jacobsen, S.E.; Patel, D.J. DNA methylation pathways and their crosstalk with histone methylation. Nat. Rev. Mol. Cell Biol. 2015, 16, 519-532. [CrossRef] [PubMed]

2. Gros, C.; Fahy, J.; Halby, L.; Dufau, I.; Erdmann, A.; Gregoire, J.-M.; Ausseil, F.; Vispé, S.; Arimondo, P.B. DNA methylation inhibitors in cancer: Recent and future approaches. Biochimie 2012, 94, 2280-2296. [CrossRef] [PubMed]

3. Yoo, C.B.; Jones, P.A. Epigenetic therapy of cancer: Past, present and future. Nat. Rev. Drug Discov. 2006, 5, 37-50. [CrossRef] [PubMed] 
4. Valente, S.; Liu, Y.; Schnekenburger, M.; Zwergel, C.; Cosconati, S.; Gros, C.; Tardugno, M.; Labella, D.; Florean, C.; Minden, S.; et al. Selective Non-nucleoside Inhibitors of Human DNA Methyltransferases Active in Cancer Including in Cancer Stem Cells. J. Med. Chem. 2014, 57, 701-713. [CrossRef] [PubMed]

5. Duymich, C.E.; Charlet, J.; Yang, X.; Jones, P.A.; Liang, G. DNMT3B isoforms without catalytic activity stimulate gene body methylation as accessory proteins in somatic cells. Nat. Commun. 2016, 7, 11453. [CrossRef] [PubMed]

6. Gopalakrishnan, S.; Van Emburgh, B.O.; Shan, J.; Su, Z.; Fields, C.R.; Vieweg, J.; Hamazaki, T.; Schwartz, P.H.; Terada, N.; Robertson, K.D. A novel DNMT3B splice variant expressed in tumor and pluripotent cells modulates genomic DNA methylation patterns and displays altered DNA binding. Mol. Cancer Res. MCR 2009, 7, 1622-1634. [CrossRef] [PubMed]

7. Rondelet, G.; Dal Maso, T.; Willems, L.; Wouters, J. Structural basis for recognition of histone H3K36me3 nucleosome by human de novo DNA methyltransferases 3A and 3B. J. Struct. Biol. 2016, 194, 357-367. [CrossRef] [PubMed]

8. Jeltsch, A.; Jurkowska, R.Z. Allosteric control of mammalian DNA methyltransferases-A new regulatory paradigm. Nucleic Acids Res. 2016, 44, 8556-8575. [CrossRef] [PubMed]

9. Lan, J.; Hua, S.; He, X.; Zhang, Y. DNA methyltransferases and methyl-binding proteins of mammals. Acta Biochim. Biophys. Sin. 2010, 42, 243-252. [CrossRef] [PubMed]

10. Suzuki, T.; Terashima, M.; Tange, S.; Ishimura, A. Roles of histone methyl-modifying enzymes in development and progression of cancer. Cancer Sci. 2013, 104, 795-800. [CrossRef] [PubMed]

11. Furukawa, Y.; Kikuchi, J. Epigenetic mechanisms of cell adhesion-mediated drug resistance in multiple myeloma. Int. J. Hematol. 2016, 104, 1-12. [CrossRef] [PubMed]

12. Morera, L.; Lübbert, M.; Jung, M. Targeting histone methyltransferases and demethylases in clinical trials for cancer therapy. Clin. Epigenet. 2016, 8, 57. [CrossRef] [PubMed]

13. Schwämmle, V.; Sidoli, S.; Ruminowicz, C.; Wu, X.; Lee, C.-F.; Helin, K.; Jensen, O.N. Systems Level Analysis of Histone H3 Post-translational Modifications (PTMs) Reveals Features of PTM Crosstalk in Chromatin Regulation. Mol. Cell. Proteom. MCP 2016, 15, 2715-2729. [CrossRef] [PubMed]

14. Baubec, T.; Colombo, D.F.; Wirbelauer, C.; Schmidt, J.; Burger, L.; Krebs, A.R.; Akalin, A.; Schübeler, D. Genomic profiling of DNA methyltransferases reveals a role for DNMT3B in genic methylation. Nature 2015, 520, 243-247. [CrossRef] [PubMed]

15. Plass, C.; Pfister, S.M.; Lindroth, A.M.; Bogatyrova, O.; Claus, R.; Lichter, P. Mutations in regulators of the epigenome and their connections to global chromatin patterns in cancer. Nat. Rev. Genet. 2013, 14, 765-780. [CrossRef] [PubMed]

16. Heerboth, S.; Lapinska, K.; Snyder, N.; Leary, M.; Rollinson, S.; Sarkar, S. Use of epigenetic drugs in disease: An overview. Genet. Epigenet. 2014, 6, 9-19. [PubMed]

17. Erdmann, A.; Halby, L.; Fahy, J.; Arimondo, P.B. Targeting DNA Methylation with Small Molecules: What's next? J. Med. Chem. 2015, 58, 2569-2583. [CrossRef] [PubMed]

18. Deltour, S.; Chopin, V.; Leprince, D. Modifications épigénétiques et cancer. Med./Sci. 2005, 21, 405-411. (in French). [CrossRef] [PubMed]

19. Tanaka, M.; Roberts, J.M.; Qi, J.; Bradner, J.E. Inhibitors of emerging epigenetic targets for cancer therapy: A patent review (2010-2014). Pharm. Pat. Anal. 2015, 4, 261-284. [CrossRef] [PubMed]

20. Xu, P.; Hu, G.; Luo, C.; Liang, Z. DNA methyltransferase inhibitors: An updated patent review (2012-2015). Expert Opin. Ther. Pat. 2016, 26, 1017-1030. [CrossRef] [PubMed]

21. Gelato, K.A.; Shaikhibrahim, Z.; Ocker, M.; Haendler, B. Targeting epigenetic regulators for cancer therapy: Modulation of bromodomain proteins, methyltransferases, demethylases, and microRNAs. Expert Opin. Ther. Targets 2016, 20, 783-799. [CrossRef] [PubMed]

22. Ye, T.; Hui, C. Synthesis of lysine methyltransferase inhibitors. Front. Chem. 2015, 3, 44.

23. Stresemann, C.; Lyko, F. Modes of action of the DNA methyltransferase inhibitors azacytidine and decitabine. Int. J. Cancer 2008, 123, 8-13. [CrossRef] [PubMed]

24. Gabbara, S.; Bhagwat, A.S. The mechanism of inhibition of DNA (cytosine-5-)-methyltransferases by 5-azacytosine is likely to involve methyl transfer to the inhibitor. Biochem. J. 1995, 307 Pt 1, 87-92. [CrossRef]

25. Kim, C.H.; Marquez, V.E.; Mao, D.T.; Haines, D.R.; McCormack, J.J. Synthesis of pyrimidin-2-one nucleosides as acid-stable inhibitors of cytidine deaminase. J. Med. Chem. 1986, 29, 1374-1380. [CrossRef] [PubMed] 
26. Cheng, J.C.; Matsen, C.B.; Gonzales, F.A.; Ye, W.; Greer, S.; Marquez, V.E.; Jones, P.A.; Selker, E.U. Inhibition of DNA methylation and reactivation of silenced genes by zebularine. J. Natl. Cancer Inst. 2003, 95, 399-409. [CrossRef] [PubMed]

27. Yoo, C.B.; Jeong, S.; Egger, G.; Liang, G.; Phiasivongsa, P.; Tang, C.; Redkar, S.; Jones, P.A. Delivery of 5-aza-2'-deoxycytidine to cells using oligodeoxynucleotides. Cancer Res. 2007, 67, 6400-6408. [CrossRef] [PubMed]

28. Brueckner, B.; Rius, M.; Markelova, M.R.; Fichtner, I.; Hals, P.-A.; Sandvold, M.L.; Lyko, F. Delivery of 5-azacytidine to human cancer cells by elaidic acid esterification increases therapeutic drug efficacy. Mol. Cancer Ther. 2010, 9, 1256-1264. [CrossRef] [PubMed]

29. Kumar, S.; Horton, J.R.; Jones, G.D.; Walker, R.T.; Roberts, R.J.; Cheng, X. DNA containing $4^{\prime}$-thio2'-deoxycytidine inhibits methylation by HhaI methyltransferase. Nucleic Acids Res. 1997, 25, 2773-2783. [CrossRef] [PubMed]

30. Thottassery, J.V.; Sambandam, V.; Allan, P.W.; Maddry, J.A.; Maxuitenko, Y.Y.; Tiwari, K.; Hollingshead, M.; Parker, W.B. Novel DNA methyltransferase-1 (DNMT1) depleting anticancer nucleosides, 4'-thio-2'-deoxycytidine and 5-aza-4'-thio-2'-deoxycytidine. Cancer Chemother. Pharmacol. 2014, 74, 291-302. [CrossRef] [PubMed]

31. Newman, E.M.; Morgan, R.J.; Kummar, S.; Beumer, J.H.; Blanchard, M.S.; Ruel, C.; El-Khoueiry, A.B.; Carroll, M.I.; Hou, J.M.; Li, C.; et al. A phase I, pharmacokinetic, and pharmacodynamic evaluation of the DNA methyltransferase inhibitor 5-fluoro-2'-deoxycytidine, administered with tetrahydrouridine. Cancer Chemother. Pharmacol. 2015, 75, 537-546. [CrossRef] [PubMed]

32. Miranda, T.B.; Cortez, C.C.; Yoo, C.B.; Liang, G.; Abe, M.; Kelly, T.K.; Marquez, V.E.; Jones, P.A. DZNep is a global histone methylation inhibitor that reactivates developmental genes not silenced by DNA methylation. Mol. Cancer Ther. 2009, 8, 1579-1588. [CrossRef] [PubMed]

33. Momparler, R.L.; Côté, S. Targeting of cancer stem cells by inhibitors of DNA and histone methylation. Expert Opin. Investig. Drugs 2015, 24, 1031-1043. [CrossRef] [PubMed]

34. Tan, J.; Cang, S.; Ma, Y.; Petrillo, R.L.; Liu, D. Novel histone deacetylase inhibitors in clinical trials as anti-cancer agents. J. Hematol. Oncol. 2010, 3, 5. [CrossRef] [PubMed]

35. Ferraris, D.; Duvall, B.; Delahanty, G.; Mistry, B.; Alt, J.; Rojas, C.; Rowbottom, C.; Sanders, K.; Schuck, E.; Huang, K.-C.; et al. Design, synthesis, and pharmacological evaluation of fluorinated tetrahydrouridine derivatives as inhibitors of cytidine deaminase. J. Med. Chem. 2014, 57, 2582-2588. [CrossRef] [PubMed]

36. Segura-Pacheco, B.; Trejo-Becerril, C.; Perez-Cardenas, E.; Taja-Chayeb, L.; Mariscal, I.; Chavez, A.; Acuña, C.; Salazar, A.M.; Lizano, M.; Dueñas-Gonzalez, A. Reactivation of tumor suppressor genes by the cardiovascular drugs hydralazine and procainamide and their potential use in cancer therapy. Clin. Cancer Res. 2003, 9, 1596-1603. [PubMed]

37. Villar-Garea, A.; Fraga, M.F.; Espada, J.; Esteller, M. Procaine is a DNA-demethylating agent with growth-inhibitory effects in human cancer cells. Cancer Res. 2003, 63, 4984-4989. [PubMed]

38. Lee, B.H.; Yegnasubramanian, S.; Lin, X.; Nelson, W.G. Procainamide is a specific inhibitor of DNA methyltransferase 1. J. Biol. Chem. 2005, 280, 40749-40756. [CrossRef] [PubMed]

39. Hossain, M.Z.; Healey, M.A.; Lee, C.; Poh, W.; Yerram, S.R.; Patel, K.; Azad, N.S.; Herman, J.G.; Kern, S.E. DNA-intercalators causing rapid re-expression of methylated and silenced genes in cancer cells. Oncotarget 2013, 4, 298-309. [CrossRef]

40. Gros, C.; Fleury, L.; Nahoum, V.; Faux, C.; Valente, S.; Labella, D.; Cantagrel, F.; Rilova, E.; Bouhlel, M.A.; David-Cordonnier, M.-H.; et al. New insights on the mechanism of quinoline-based DNA Methyltransferase inhibitors. J. Biol. Chem. 2015, 290, 6293-6302. [CrossRef] [PubMed]

41. Datta, J.; Ghoshal, K.; Denny, W.A.; Gamage, S.A.; Brooke, D.G.; Phiasivongsa, P.; Redkar, S.; Jacob, S.T. A New Class of Quinoline-Based DNA Hypomethylating Agents Reactivates Tumor Suppressor Genes by Blocking DNA Methyltransferase 1 Activity and Inducing Its Degradation. Cancer Res. 2009, 69, 4277-4285. [CrossRef] [PubMed]

42. Gamage, S.A.; Brooke, D.G.; Redkar, S.; Datta, J.; Jacob, S.T.; Denny, W.A. Structure-activity relationships for 4-anilinoquinoline derivatives as inhibitors of the DNA methyltransferase enzyme DNMT1. Bioorg. Med. Chem. 2013, 21, 3147-3153. [CrossRef] [PubMed]

43. Rilova, E.; Erdmann, A.; Gros, C.; Masson, V.; Aussagues, Y.; Poughon-Cassabois, V.; Rajavelu, A.; Jeltsch, A.; Menon, Y.; Novosad, N.; et al. Design, Synthesis and Biological Evaluation of 
4-Amino-N-(4-aminophenyl)benzamide Analogues of Quinoline-Based SGI-1027 as Inhibitors of DNA Methylation. ChemMedChem 2014, 9, 590-601. [CrossRef] [PubMed]

44. Fagan, R.L.; Cryderman, D.E.; Kopelovich, L.; Wallrath, L.L.; Brenner, C. Laccaic acid A is a direct, DNA-competitive inhibitor of DNA methyltransferase 1. J. Biol. Chem. 2013, 288, 23858-23867. [CrossRef] [PubMed]

45. Halby, L.; Champion, C.; Sénamaud-Beaufort, C.; Ajjan, S.; Drujon, T.; Rajavelu, A.; Ceccaldi, A.; Jurkowska, R.; Lequin, O.; Nelson, W.G.; et al. Rapid Synthesis of New DNMT Inhibitors Derivatives of Procainamide. ChemBioChem 2012, 13, 157-165. [CrossRef] [PubMed]

46. Asgatay, S.; Champion, C.; Marloie, G.; Drujon, T.; Senamaud-Beaufort, C.; Ceccaldi, A.; Erdmann, A.; Rajavelu, A.; Schambel, P.; Jeltsch, A.; et al. Synthesis and evaluation of analogues of N-Phthaloyl-l-tryptophan (RG108) as Inhibitors of DNA Methyltransferase 1. J. Med. Chem. 2014, 57, 421-434. [CrossRef] [PubMed]

47. Suzuki, T.; Tanaka, R.; Hamada, S.; Nakagawa, H.; Miyata, N. Design, synthesis, inhibitory activity, and binding mode study of novel DNA methyltransferase 1 inhibitors. Bioorg. Med. Chem. Lett. 2010, 20, 1124-1127. [CrossRef] [PubMed]

48. Castellano, S.; Kuck, D.; Viviano, M.; Yoo, J.; López-Vallejo, F.; Conti, P.; Tamborini, L.; Pinto, A.; Medina-Franco, J.L.; Sbardella, G. Synthesis and biochemical evaluation of $\Delta^{2}$-isoxazoline derivatives as DNA methyltransferase 1 inhibitors. J. Med. Chem. 2011, 54, 7663-7677. [CrossRef] [PubMed]

49. Chen, L.-L.; Han, W.-F.; Geng, Y.; Su, J.-S. A genome-wide study of DNA methylation modified by epigallocatechin-3-gallate in the CAL-27 cell line. Mol. Med. Rep. 2015, 12, 5886-5890. [CrossRef] [PubMed]

50. Nandakumar, V.; Vaid, M.; Katiyar, S.K. (-)-Epigallocatechin-3-gallate reactivates silenced tumor suppressor genes, Cip1/p21 and p16 $6^{I N K 4 a}$, by reducing DNA methylation and increasing histones acetylation in human skin cancer cells. Carcinogenesis 2011, 32, 537-544. [CrossRef] [PubMed]

51. Ceccaldi, A.; Rajavelu, A.; Champion, C.; Rampon, C.; Jurkowska, R.; Jankevicius, G.; Sénamaud-Beaufort, C.; Ponger, L.; Gagey, N.; Dali Ali, H.; et al. C5-DNA methyltransferase inhibitors: From screening to effects on zebrafish embryo development. ChemBioChem 2011, 12, 1337-1345. [CrossRef] [PubMed]

52. Kuck, D.; Caulfield, T.; Lyko, F.; Medina-Franco, J.L. Nanaomycin A selectively inhibits DNMT3B and reactivates silenced tumor suppressor genes in human cancer cells. Mol. Cancer Ther. 2010, 9, 3015-3023. [CrossRef] [PubMed]

53. Kilgore, J.A.; Du, X.; Melito, L.; Wei, S.; Wang, C.; Chin, H.G.; Posner, B.; Pradhan, S.; Ready, J.M.; Williams, N.S. Identification of DNMT1 selective antagonists using a novel scintillation proximity assay. J. Biol. Chem. 2013, 288, 19673-19684. [CrossRef] [PubMed]

54. Ruscio, A.D.; Ebralidze, A.K.; Tenen, D.G.; Leone, G. Chimeric RNA Oligonucleotides and Uses Thereof. U.S. Patent 20140171492 A1, 18 October 2012.

55. Pradhan, S.; Esteve, P.; Zhang, G. Dnmt Inhibitors. Patent WO2015073360, 21 May 2015.

56. Sledziewski, A.; Devos, T.; Kole, R. Oligonucleotide Inhibitors of DNA Methyltransferases and Their Use in Treating Diseases. Patent WO2014011573, 18 June 2015.

57. Winquist, E.; Knox, J.; Ayoub, J.-P.; Wood, L.; Wainman, N.; Reid, G.K.; Pearce, L.; Shah, A.; Eisenhauer, E. Phase II trial of DNA methyltransferase 1 inhibition with the antisense oligonucleotide MG98 in patients with metastatic renal carcinoma: A National Cancer Institute of Canada Clinical Trials Group investigational new drug study. Investig. New Drugs 2006, 24, 159-167. [CrossRef] [PubMed]

58. Amato, R.J.; Stephenson, J.; Hotte, S.; Nemunaitis, J.; Bélanger, K.; Reid, G.; Martell, R.E. MG98, a second-generation DNMT1 inhibitor, in the treatment of advanced renal cell carcinoma. Cancer Investig. 2012, 30, 415-421. [CrossRef] [PubMed]

59. Garzon, R.; Heaphy, C.E.A.; Havelange, V.; Fabbri, M.; Volinia, S.; Tsao, T.; Zanesi, N.; Kornblau, S.M.; Marcucci, G.; Calin, G.A.; et al. MicroRNA 29b functions in acute myeloid leukemia. Blood 2009, 114, 5331-5341. [CrossRef] [PubMed]

60. Amodio, N.; Rossi, M.; Raimondi, L.; Pitari, M.R.; Botta, C.; Tagliaferri, P.; Tassone, P. miR-29s: A family of epi-miRNAs with therapeutic implications in hematologic malignancies. Oncotarget 2015, 6, 12837-12861. [CrossRef] [PubMed]

61. Stewart, D.J.; Donehower, R.C.; Eisenhauer, E.A.; Wainman, N.; Shah, A.K.; Bonfils, C.; MacLeod, A.R.; Besterman, J.M.; Reid, G.K. A phase I pharmacokinetic and pharmacodynamic study of the DNA 
methyltransferase 1 inhibitor MG98 administered twice weekly. Ann. Oncol. 2003, 14, 766-774. [CrossRef] [PubMed]

62. Davis, A.J.; Gelmon, K.A.; Siu, L.L.; Moore, M.J.; Britten, C.D.; Mistry, N.; Klamut, H.; D'Aloisio, S.; MacLean, M.; Wainman, N.; et al. Phase I and pharmacologic study of the human DNA methyltransferase antisense oligodeoxynucleotide MG98 given as a 21-day continuous infusion every 4 weeks. Investig. New Drugs 2003, 21, 85-97. [CrossRef]

63. Klisovic, R.B.; Stock, W.; Cataland, S.; Klisovic, M.I.; Liu, S.; Blum, W.; Green, M.; Odenike, O.; Godley, L.; Burgt, J.V.; et al. A phase I biological study of MG98, an oligodeoxynucleotide antisense to DNA methyltransferase 1, in patients with high-risk myelodysplasia and acute myeloid leukemia. Clin. Cancer Res. 2008, 14, 2444-2449. [CrossRef] [PubMed]

64. Plummer, R.; Vidal, L.; Griffin, M.; Lesley, M.; de Bono, J.; Coulthard, S.; Sludden, J.; Siu, L.L.; Chen, E.X.; Oza, A.M.; et al. Phase I study of MG98, an oligonucleotide antisense inhibitor of human DNA methyltransferase 1, given as a 7-day infusion in patients with advanced solid tumors. Clin. Cancer Res. 2009, 15, 3177-3183. [CrossRef] [PubMed]

65. Jiang, H.; Zhang, G.; Wu, J.-H.; Jiang, C.-P. Diverse roles of miR-29 in cancer (review). Oncol. Rep. 2014, 31, 1509-1516. [CrossRef] [PubMed]

66. Cattaneo, M.; Pelosi, E.; Castelli, G.; Cerio, A.M.; D’Angiò, A.; Porretti, L.; Rebulla, P.; Pavesi, L.; Russo, G.; Giordano, A.; et al. A miRNA Signature in Human Cord Blood Stem and Progenitor Cells as Potential Biomarker of Specific Acute Myeloid Leukemia Subtypes. J. Cell. Physiol. 2015, 230, 1770-1780. [CrossRef] [PubMed]

67. Yan, B.; Guo, Q.; Fu, F.-J.; Wang, Z.; Yin, Z.; Wei, Y.-B.; Yang, J.-R. The role of miR-29b in cancer: Regulation, function, and signaling. OncoTargets Ther. 2015, 8, 539-548.

68. Guo, Z.S.; Hong, J.A.; Irvine, K.R.; Chen, G.A.; Spiess, P.J.; Liu, Y.; Zeng, G.; Wunderlich, J.R.; Nguyen, D.M.; Restifo, N.P.; et al. De novo induction of a cancer/testis antigen by 5-aza-2'-deoxycytidine augments adoptive immunotherapy in a murine tumor model. Cancer Res. 2006, 66, 1105-1113. [CrossRef] [PubMed]

69. Xiao, W.; Dong, W. Double-chain siRNA Molecule of Silencing DNMT (Desoxvribose Nucleic Acid Methyltransferases) Gene and Application of Double-Chain siRNA Molecule. Patent CN 201410021188, 30 April 2014.

70. Siedlecki, P.; Boy, R.G.; Musch, T.; Brueckner, B.; Suhai, S.; Lyko, F.; Zielenkiewicz, P. Discovery of Two Novel, Small-Molecule Inhibitors of DNA Methylation. J. Med. Chem. 2006, 49, 678-683. [CrossRef] [PubMed]

71. Brueckner, B.; Garcia Boy, R.; Siedlecki, P.; Musch, T.; Kliem, H.C.; Zielenkiewicz, P.; Suhai, S.; Wiessler, M.; Lyko, F. Epigenetic reactivation of tumor suppressor genes by a novel small-molecule inhibitor of human DNA methyltransferases. Cancer Res. 2005, 65, 6305-6311. [CrossRef] [PubMed]

72. Castellano, S.; Kuck, D.; Sala, M.; Novellino, E.; Lyko, F.; Sbardella, G. Constrained analogues of procaine as novel small molecule inhibitors of DNA methyltransferase-1. J. Med. Chem. 2008, 51, 2321-2325. [CrossRef] [PubMed]

73. Lillico, R.; Stesco, N.; Khorshid Amhad, T.; Cortes, C.; Namaka, M.P.; Lakowski, T.M. Inhibitors of enzymes catalyzing modifications to histone lysine residues: Structure, function and activity. Future Med. Chem. 2016, 8, 879-897. [CrossRef] [PubMed]

74. Nguyen, C.T.; Weisenberger, D.J.; Velicescu, M.; Gonzales, F.A.; Lin, J.C.Y.; Liang, G.; Jones, P.A. Histone H3-lysine 9 methylation is associated with aberrant gene silencing in cancer cells and is rapidly reversed by 5-aza-2'-deoxycytidine. Cancer Res. 2002, 62, 6456-6461. [PubMed]

75. Andresini, O.; Ciotti, A.; Rossi, M.N.; Battistelli, C.; Carbone, M.; Maione, R. A cross-talk between DNA methylation and $\mathrm{H} 3$ lysine 9 dimethylation at the KvDMR1 region controls the induction of $\mathrm{Cdkn1c}$ in muscle cells. Epigenetics 2016, 11, 793-801. [CrossRef] [PubMed]

76. Das, S.; Chadwick, B.P. Influence of Repressive Histone and DNA Methylation upon D4Z4 Transcription in Non-Myogenic Cells. PLoS ONE 2016, 11, e0160022. [CrossRef] [PubMed]

77. Tachibana, M.; Matsumura, Y.; Fukuda, M.; Kimura, H.; Shinkai, Y. G9a/GLP complexes independently mediate H3K9 and DNA methylation to silence transcription. EMBO J. 2008, 27, 2681-2690. [CrossRef] [PubMed]

78. Tachibana, M.; Ueda, J.; Fukuda, M.; Takeda, N.; Ohta, T.; Iwanari, H.; Sakihama, T.; Kodama, T.; Hamakubo, T.; Shinkai, Y. Histone methyltransferases G9a and GLP form heteromeric complexes and are both crucial for methylation of euchromatin at H3-K9. Genes Dev. 2005, 19, 815-826. [CrossRef] [PubMed] 
79. Casciello, F.; Windloch, K.; Gannon, F.; Lee, J.S. Functional Role of G9a Histone Methyltransferase in Cancer. Front. Immunol. 2015, 6, 487. [CrossRef] [PubMed]

80. Ding, J.; Li, T.; Wang, X.; Zhao, E.; Choi, J.-H.; Yang, L.; Zha, Y.; Dong, Z.; Huang, S.; Asara, J.M.; et al. The histone H3 methyltransferase G9A epigenetically activates the serine-glycine synthesis pathway to sustain cancer cell survival and proliferation. Cell Metab. 2013, 18, 896-907. [CrossRef] [PubMed]

81. Kubicek, S.; O'Sullivan, R.J.; August, E.M.; Hickey, E.R.; Zhang, Q.; Teodoro, M.L.; Rea, S.; Mechtler, K.; Kowalski, J.A.; Homon, C.A.; et al. Reversal of H3K9me2 by a Small-Molecule Inhibitor for the G9a Histone Methyltransferase. Mol. Cell 2007, 25, 473-481. [CrossRef] [PubMed]

82. Soumyanarayanan, U.; Dymock, B.W. Recently discovered EZH2 and EHMT2 (G9a) inhibitors. Future Med. Chem. 2016, 8, 1635-1654. [CrossRef] [PubMed]

83. Yuan, Y.; Wang, Q.; Paulk, J.; Kubicek, S.; Kemp, M.M.; Adams, D.J.; Shamji, A.F.; Wagner, B.K.; Schreiber, S.L. A Small-Molecule Probe of the Histone Methyltransferase G9a Induces Cellular Senescence in Pancreatic Adenocarcinoma. ACS Chem. Biol. 2012, 7, 1152-1157. [CrossRef] [PubMed]

84. Rotili, D.; Tarantino, D.; Marrocco, B.; Gros, C.; Masson, V.; Poughon, V.; Ausseil, F.; Chang, Y.; Labella, D.; Cosconati, S.; et al. Properly Substituted Analogues of BIX-01294 Lose Inhibition of G9a Histone Methyltransferase and Gain Selective Anti-DNA Methyltransferase 3A Activity. PLoS ONE 2014, 9, e96941. [CrossRef] [PubMed]

85. Dong, K.B.; Maksakova, I.A.; Mohn, F.; Leung, D.; Appanah, R.; Lee, S.; Yang, H.W.; Lam, L.L.; Mager, D.L.; Schübeler, D.; et al. DNA methylation in ES cells requires the lysine methyltransferase G9a but not its catalytic activity. EMBO J. 2008, 27, 2691-2701. [CrossRef] [PubMed]

86. Epsztejn-Litman, S.; Feldman, N.; Abu-Remaileh, M.; Shufaro, Y.; Gerson, A.; Ueda, J.; Deplus, R.; Fuks, F.; Shinkai, Y.; Cedar, H.; et al. De novo DNA methylation promoted by G9a prevents reprogramming of embryonically silenced genes. Nat. Struct. Mol. Biol. 2008, 15, 1176-1183. [CrossRef] [PubMed]

87. Chang, Y.; Sun, L.; Kokura, K.; Horton, J.R.; Fukuda, M.; Espejo, A.; Izumi, V.; Koomen, J.M.; Bedford, M.T.; Zhang, X.; et al. MPP8 mediates the interactions between DNA methyltransferase Dnmt3a and H3K9 methyltransferase GLP/G9a. Nat. Commun. 2011, 2, 533. [CrossRef] [PubMed]

88. Zhang, T.; Termanis, A.; Özkan, B.; Bao, X.X.; Culley, J.; de Lima Alves, F.; Rappsilber, J.; Ramsahoye, B.; Stancheva, I. G9a/GLP Complex maintains imprinted DNA methylation in embryonic stem cells. Cell Rep. 2016, 15, 77-85. [CrossRef] [PubMed]

89. Kuntz, K.; Chesworth, R.; Duncan, K.; Keilhack, H.; Warholic, N.; Klaus, C.; Seki, M.; Shirotori, S.; Kawano, S.; Wigle, T.J.N. Aryl-or Heteroaryl-Substituted Benzene Compounds. WO/2012/142504, 2012.

90. McCabe, M.T.; Ott, H.M.; Ganji, G.; Korenchuk, S.; Thompson, C.; Van Aller, G.S.; Liu, Y.; Graves, A.P.; Della Pietra, A.; Diaz, E.; et al. EZH2 inhibition as a therapeutic strategy for lymphoma with EZH2-activating mutations. Nature 2012, 492, 108-112. [CrossRef] [PubMed]

91. Bradley, W.D.; Arora, S.; Busby, J.; Balasubramanian, S.; Gehling, V.S.; Nasveschuk, C.G.; Vaswani, R.G.; Yuan, C.-C.; Hatton, C.; Zhao, F.; et al. EZH2 inhibitor efficacy in non-Hodgkin's lymphoma does not require suppression of H3K27 monomethylation. Chem. Biol. 2014, 21, 1463-1475. [CrossRef] [PubMed]

92. Olhava, E.J.; Chesworth, R.; Kuntz, K. Carbocycle-Substituted Purine and 7-Deazapurine Compounds. WO/2012/075492, 2012.

93. Daigle, S.R.; Olhava, E.J.; Therkelsen, C.A.; Basavapathruni, A.; Jin, L.; Boriack-Sjodin, P.A.; Allain, C.J.; Klaus, C.R.; Raimondi, A.; Scott, M.P.; et al. Potent inhibition of DOT1L as treatment of MLL-fusion leukemia. Blood 2013, 122, 1017-1025. [CrossRef] [PubMed]

94. Lipka, D.B.; Kuck, D.; Kliem, C.; Gerhauser, C. Substituted purine and 7-deazapurine compounds as modulators of epigenetic enzymes: A patent evaluation (WO2012075381). Expert Opin. Ther. Pat. 2013, 23, 537-543. [CrossRef] [PubMed]

95. Viré, E.; Brenner, C.; Deplus, R.; Blanchon, L.; Fraga, M.; Didelot, C.; Morey, L.; Van Eynde, A.; Bernard, D.; Vanderwinden, J.-M.; et al. The Polycomb group protein EZH2 directly controls DNA methylation. Nature 2006, 439, 871-874. [CrossRef] [PubMed]

96. Moison, C.; Senamaud-Beaufort, C.; Fourrière, L.; Champion, C.; Ceccaldi, A.; Lacomme, S.; Daunay, A.; Tost, J.; Arimondo, P.B.; Guieysse-Peugeot, A.-L. DNA methylation associated with polycomb repression in retinoic acid receptor $\beta$ silencing. FASEB J. 2013, 27, 1468-1478. [CrossRef] [PubMed] 
97. Moison, C.; Assemat, F.; Daunay, A.; Tost, J.; Guieysse-Peugeot, A.-L.; Arimondo, P.B. Synergistic chromatin repression of the tumor suppressor gene RARB in human prostate cancers. Epigenetics 2014, 9, 477-482. [CrossRef] [PubMed]

98. Ning, X.; Shi, Z.; Liu, X.; Zhang, A.; Han, L.; Jiang, K.; Kang, C.; Zhang, Q. DNMT1 and EZH2 mediated methylation silences the microRNA-200b/a/429 gene and promotes tumor progression. Cancer Lett. 2015, 359, 198-205. [CrossRef] [PubMed]

99. Nichol, J.N.; Dupéré-Richer, D.; Ezponda, T.; Licht, J.D.; Miller, W.H. H3K27 Methylation: A Focal Point of Epigenetic Deregulation in Cancer. Adv. Cancer Res. 2016, 131, 59-95. [PubMed]

100. Balasubramanian, V.; Iyer, P.; Arora, S.; Troyer, P.; Normant, E. Abstract 1697: CPI-169, a novel and potent EZH2 inhibitor, synergizes with CHOP in vivo and achieves complete regression in lymphoma xenograft models. Cancer Res. 2014, 74, 1697. [CrossRef]

101. Daigle, S.R.; Olhava, E.J.; Therkelsen, C.A.; Majer, C.R.; Sneeringer, C.J.; Song, J.; Johnston, L.D.; Scott, M.P.; Smith, J.J.; Xiao, Y.; et al. Selective Killing of Mixed Lineage Leukemia Cells by a Potent Small-Molecule DOT1L Inhibitor. Cancer Cell 2011, 20, 53-65. [CrossRef] [PubMed]

102. Nguyen, A.T.; Zhang, Y. The diverse functions of Dot1 and H3K79 methylation. Genes Dev. 2011, 25, 1345-1358. [CrossRef] [PubMed]

103. Anglin, J.L.; Song, Y. A medicinal chemistry perspective for targeting histone H3 lysine-79 methyltransferase DOT1L. J. Med. Chem. 2013, 56, 8972-8983. [CrossRef] [PubMed]

104. Wong, M.; Polly, P.; Liu, T. The histone methyltransferase DOT1L: Regulatory functions and a cancer therapy target. Am. J. Cancer Res. 2015, 5, 2823-2837. [PubMed]

105. Wang, X.; Chen, C.-W.; Armstrong, S.A. The role of DOT1L in the maintenance of leukemia gene expression. Curr. Opin. Genet. Dev. 2016, 36, 68-72. [CrossRef] [PubMed]

106. Farooq, Z.; Banday, S.; Pandita, T.K.; Altaf, M. The many faces of histone H3K79 methylation. Mutat. Res. Mutat. Res. 2016, 768, 46-52. [CrossRef] [PubMed]

107. Vlaming, H.; van Leeuwen, F. The upstreams and downstreams of H3K79 methylation by DOT1L. Chromosoma 2016, 125, 593-605. [CrossRef] [PubMed]

108. Tomizawa, D. Recent progress in the treatment of infant acute lymphoblastic leukemia. Pediatr. Int. 2015, 57, 811-819. [CrossRef] [PubMed]

109. Spurr, S.S.; Bayle, E.D.; Yu, W.; Li, F.; Tempel, W.; Vedadi, M.; Schapira, M.; Fish, P.V. New small molecule inhibitors of histone methyl transferase DOT1L with a nitrile as a non-traditional replacement for heavy halogen atoms. Bioorg. Med. Chem. Lett. 2016, 26, 4518-4522. [CrossRef] [PubMed]

110. Deng, L.; Zhang, L.; Yao, Y.; Wang, C.; Redell, M.S.; Dong, S.; Song, Y. Synthesis, activity and metabolic stability of non-ribose containing inhibitors of histone methyltransferase DOT1L. MedChemComm 2013, 4, 822-826. [CrossRef] [PubMed]

111. Chen, C.; Zhu, H.; Stauffer, F.; Caravatti, G.; Vollmer, S.; Machauer, R.; Holzer, P.; Möbitz, H.; Scheufler, C.; Klumpp, M.; et al. Discovery of Novel Dot1L Inhibitors through a Structure-Based Fragmentation Approach. ACS Med. Chem. Lett. 2016, 7, 735-740. [CrossRef] [PubMed]

112. Scheufler, C.; Möbitz, H.; Gaul, C.; Ragot, C.; Be, C.; Fernández, C.; Beyer, K.S.; Tiedt, R.; Stauffer, F. Optimization of a Fragment-Based Screening Hit toward Potent DOT1L Inhibitors Interacting in an Induced Binding Pocket. ACS Med. Chem. Lett. 2016, 7, 730-734. [CrossRef] [PubMed]

113. Luo, M.; Wang, H.; Zou, Y.; Zhang, S.; Xiao, J.; Jiang, G.; Zhang, Y.; Lai, Y. Identification of phenoxyacetamide derivatives as novel DOT1L inhibitors via docking screening and molecular dynamics simulation. J. Mol. Graph. Model. 2016, 68, 128-139. [CrossRef] [PubMed]

114. Chen, S.; Li, L.; Chen, Y.; Hu, J.; Liu, J.; Liu, Y.-C.; Liu, R.; Zhang, Y.; Meng, F.; Zhu, K.; et al. Identification of Novel Disruptor of Telomeric Silencing 1-like (DOT1L) Inhibitors through Structure-Based Virtual Screening and Biological Assays. J. Chem. Inf. Model. 2016, 56, 527-534. [CrossRef] [PubMed]

115. Knutson, S.K.; Warholic, N.M.; Wigle, T.J.; Klaus, C.R.; Allain, C.J.; Raimondi, A.; Porter Scott, M.; Chesworth, R.; Moyer, M.P.; Copeland, R.A.; et al. Durable tumor regression in genetically altered malignant rhabdoid tumors by inhibition of methyltransferase EZH2. Proc. Natl. Acad. Sci. USA 2013, 110, 7922-7927. [CrossRef] [PubMed]

116. Olhava, E.; Chesworth, R.; Kuntz, K.; Richon, V.; Pollock, R.; Daigle, S. Method of Treating Leukemia. WO2014039839, 13 March 2014. 
117. Selvi, B.R.; Batta, K.; Kishore, A.H.; Mantelingu, K.; Varier, R.A.; Balasubramanyam, K.; Pradhan, S.K.; Dasgupta, D.; Sriram, S.; Agrawal, S.; et al. Identification of a novel inhibitor of coactivator-associated arginine methyltransferase 1 (CARM1)-mediated methylation of histone H3 Arg-17. J. Biol. Chem. 2010, 285, 7143-7152. [CrossRef] [PubMed]

118. Chan-Penebre, E.; Kuplast, K.G.; Majer, C.R.; Boriack-Sjodin, P.A.; Wigle, T.J.; Johnston, L.D.; Rioux, N.; Munchhof, M.J.; Jin, L.; Jacques, S.L.; et al. A selective inhibitor of PRMT5 with in vivo and in vitro potency in MCL models. Nat. Chem. Biol. 2015, 11, 432-437. [CrossRef] [PubMed]

119. Feng, Q.; Yi, P.; Wong, J.; O'Malley, B.W. Signaling within a coactivator complex: Methylation of SRC-3/AIB1 is a molecular switch for complex disassembly. Mol. Cell. Biol. 2006, 26, 7846-7857. [CrossRef] [PubMed]

120. Van Haren, M.; van Ufford, L.Q.; Moret, E.E.; Martin, N.I. Synthesis and evaluation of protein arginine $N$-methyltransferase inhibitors designed to simultaneously occupy both substrate binding sites. Org. Biomol. Chem. 2015, 13, 549-560. [CrossRef] [PubMed]

121. Jahan, S.; Davie, J.R. Protein arginine methyltransferases (PRMTs): Role in chromatin organization. Adv. Biol. Regul. 2015, 57, 173-184. [CrossRef] [PubMed]

122. Sheng, X.; Wang, Z. Protein arginine methyltransferase 5 regulates multiple signaling pathways to promote lung cancer cell proliferation. BMC Cancer 2016, 16, 567. [CrossRef] [PubMed]

123. Kanda, M.; Shimizu, D.; Fujii, T.; Tanaka, H.; Shibata, M.; Iwata, N.; Hayashi, M.; Kobayashi, D.; Tanaka, C.; Yamada, S.; et al. Protein arginine methyltransferase 5 is associated with malignant phenotype and peritoneal metastasis in gastric cancer. Int. J. Oncol. 2016, 49, 1195-1202. [CrossRef] [PubMed]

124. Rioux, N.; Duncan, K.W.; Lantz, R.J.; Miao, X.; Chan-Penebre, E.; Moyer, M.P.; Munchhof, M.J.; Copeland, R.A.; Chesworth, R.; Waters, N.J. Species differences in metabolism of EPZ015666, an oxetane-containing protein arginine methyltransferase-5 (PRMT5) inhibitor. Xenobiotica Fate Foreign Compd. Biol. Syst. 2016, 46, 268-277. [CrossRef] [PubMed]

125. Epizyme Inc. Epizyme Earns \$6 Million Milestone Payment from GlaxoSmithKline for Initiation of Clinical Development with First-in-Class PRMT5 Inhibitor. Available online: http://globenewswire. com/news-release/2016/09/15/872059/0/en/Epizyme-Earns-6-Million-Milestone-Payment-fromGlaxoSmithKline-for-Initiation-of-Clinical-Development-with-First-in-Class-PRMT5-Inhibitor.html (accessed on 15 September 2016).

126. Erdmann, A.; Menon, Y.; Gros, C.; Masson, V.; Aussagues, Y.; Ausseil, F.; Novosad, N.; Schambel, P.; Baltas, M.; Arimondo, P.B. Identification and optimization of hydrazone-gallate derivatives as specific inhibitors of DNA methyltransferase 3A. Future Med. Chem. 2016, 8, 373-380. [CrossRef] [PubMed]

127. Aldawsari, F.S.; Aguayo-Ortiz, R.; Kapilashrami, K.; Yoo, J.; Luo, M.; Medina-Franco, J.L.; Velázquez-Martínez, C.A. Resveratrol-salicylate derivatives as selective DNMT3 inhibitors and anticancer agents. J. Enzyme Inhib. Med. Chem. 2016, 31, 695-703. [CrossRef] [PubMed]

128. Halby, L.; Arimondo, P.B. Quinazoline Derivatives and Their Use as DNA Methyltransferase Inhibitors. Patent WO2015040169, 26 March 2015.

129. Yost, J.M.; Korboukh, I.; Liu, F.; Gao, C.; Jin, J. Targets in epigenetics: Inhibiting the methyl writers of the histone code. Curr. Chem. Genom. 2011, 5, 72-84. [CrossRef] [PubMed]

130. Yu, W.; Chory, E.J.; Wernimont, A.K.; Tempel, W.; Scopton, A.; Federation, A.; Marineau, J.J.; Qi, J.; Barsyte-Lovejoy, D.; Yi, J.; et al. Catalytic site remodelling of the DOT1L methyltransferase by selective inhibitors. Nat. Commun. 2012, 3, 1288. [CrossRef] [PubMed]

131. Ruiz-Magaña, M.J.; Martínez-Aguilar, R.; Lucendo, E.; Campillo-Davo, D.; Schulze-Osthoff, K.; Ruiz-Ruiz, C. The antihypertensive drug hydralazine activates the intrinsic pathway of apoptosis and causes DNA damage in leukemic T cells. Oncotarget 2016, 7, 21875-21886. [PubMed]

132. Deng, C.; Lu, Q.; Zhang, Z.; Rao, T.; Attwood, J.; Yung, R.; Richardson, B. Hydralazine may induce autoimmunity by inhibiting extracellular signal-regulated kinase pathway signaling. Arthritis Rheum. 2003, 48, 746-756. [CrossRef] [PubMed]

133. Singh, N.; Dueñas-González, A.; Lyko, F.; Medina-Franco, J.L. Molecular modeling and molecular dynamics studies of hydralazine with human DNA methyltransferase 1. ChemMedChem 2009, 4, 792-799. [CrossRef] [PubMed]

134. Dueñas-Gonzalez, A.; Coronel, J.; Cetina, L.; González-Fierro, A.; Chavez-Blanco, A.; Taja-Chayeb, L. Hydralazine-valproate: A repositioned drug combination for the epigenetic therapy of cancer. Expert Opin. Drug Metab. Toxicol. 2014, 10, 1433-1444. [CrossRef] [PubMed] 
135. Candelaria, M.; Herrera, A.; Labardini, J.; González-Fierro, A.; Trejo-Becerril, C.; Taja-Chayeb, L.; Pérez-Cárdenas, E.; de la Cruz-Hernández, E.; Arias-Bofill, D.; Vidal, S.; et al. Hydralazine and magnesium valproate as epigenetic treatment for myelodysplastic syndrome. Preliminary results of a phase-II trial. Ann. Hematol. 2011, 90, 379-387. [CrossRef] [PubMed]

136. Fang, M.Z.; Wang, Y.; Ai, N.; Hou, Z.; Sun, Y.; Lu, H.; Welsh, W.; Yang, C.S. Tea polyphenol (-)-epigallocatechin-3-gallate inhibits DNA methyltransferase and reactivates methylation-silenced genes in cancer cell lines. Cancer Res. 2003, 63, 7563-7570. [PubMed]

137. Lee, W.J.; Shim, J.-Y.; Zhu, B.T. Mechanisms for the inhibition of DNA methyltransferases by tea catechins and bioflavonoids. Mol. Pharmacol. 2005, 68, 1018-1030. [CrossRef] [PubMed]

138. Shilpi, A.; Parbin, S.; Sengupta, D.; Kar, S.; Deb, M.; Rath, S.K.; Pradhan, N.; Rakshit, M.; Patra, S.K. Mechanisms of DNA methyltransferase-inhibitor interactions: Procyanidin B2 shows new promise for therapeutic intervention of cancer. Chem. Biol. Interact. 2015, 233, 122-138. [CrossRef] [PubMed]

139. Moseley, V.R.; Morris, J.; Knackstedt, R.W.; Wargovich, M.J. Green tea polyphenol epigallocatechin 3-gallate, contributes to the degradation of DNMT3A and HDAC3 in HCT 116 human colon cancer cells. Anticancer Res. 2013, 33, 5325-5333. [PubMed]

140. Forester, S.C.; Lambert, J.D. Synergistic inhibition of lung cancer cell lines by (-)-epigallocatechin-3-gallate in combination with clinically used nitrocatechol inhibitors of catechol-O-methyltransferase. Carcinogenesis 2014, 35, 365-372. [CrossRef] [PubMed]

141. Busch, C.; Burkard, M.; Leischner, C.; Lauer, U.M.; Frank, J.; Venturelli, S. Epigenetic activities of flavonoids in the prevention and treatment of cancer. Clin. Epigenet. 2015, 7, 1-18. [CrossRef] [PubMed]

142. Caulfield, T.; Medina-Franco, J.L. Molecular dynamics simulations of human DNA methyltransferase 3B with selective inhibitor nanaomycin A. J. Struct. Biol. 2011, 176, 185-191. [CrossRef] [PubMed]

143. Medina-Franco, J.L.; Méndez-Lucio, O.; Yoo, J. Rationalization of activity cliffs of a sulfonamide inhibitor of DNA methyltransferases with induced-fit docking. Int. J. Mol. Sci. 2014, 15, 3253-3261. [CrossRef] [PubMed]

144. Rogawski, D.S.; Grembecka, J.; Cierpicki, T. H3K36 methyltransferases as cancer drug targets: Rationale and perspectives for inhibitor development. Future Med. Chem. 2016, 8, 1589-1607. [CrossRef] [PubMed]

145. Zhang, Y.; Jurkowska, R.; Soeroes, S.; Rajavelu, A.; Dhayalan, A.; Bock, I.; Rathert, P.; Brandt, O.; Reinhardt, R.; Fischle, W.; et al. Chromatin methylation activity of Dnmt3a and Dnmt3a/3L is guided by interaction of the ADD domain with the histone H3 tail. Nucleic Acids Res. 2010, 38, 4246-4253. [CrossRef] [PubMed]

146. Bashtrykov, P.; Jankevicius, G.; Jurkowska, R.Z.; Ragozin, S.; Jeltsch, A. The UHRF1 protein stimulates the activity and specificity of the maintenance DNA methyltransferase DNMT1 by an allosteric mechanism. J. Biol. Chem. 2014, 289, 4106-4115. [CrossRef] [PubMed]

147. Rottach, A.; Frauer, C.; Pichler, G.; Bonapace, I.M.; Spada, F.; Leonhardt, H. The multi-domain protein Np95 connects DNA methylation and histone modification. Nucleic Acids Res. 2010, 38, 1796-1804. [CrossRef] [PubMed]

148. Karagianni, P.; Amazit, L.; Qin, J.; Wong, J. ICBP90, a novel methyl K9 H3 binding protein linking protein ubiquitination with heterochromatin formation. Mol. Cell. Biol. 2008, 28, 705-717. [CrossRef] [PubMed]

149. Cheray, M.; Nadaradjane, A.; Bonnet, P.; Routier, S.; Vallette, F.M.; Cartron, P.-F. Specific inhibition of DNMT1/CFP1 reduces cancer phenotypes and enhances chemotherapy effectiveness. Epigenomics 2014, 6, 267-275. [CrossRef] [PubMed]

150. Myrianthopoulos, V.; Cartron, P.F.; Liutkevičiūte, Z.; Klimašauskas, S.; Matulis, D.; Bronner, C.; Martinet, N.; Mikros, E. Tandem virtual screening targeting the SRA domain of UHRF1 identifies a novel chemical tool modulating DNA methylation. Eur. J. Med. Chem. 2016, 114, 390-396. [CrossRef] [PubMed]

151. Liu, X.S.; Wu, H.; Ji, X.; Stelzer, Y.; Wu, X.; Czauderna, S.; Shu, J.; Dadon, D.; Young, R.A.; Jaenisch, R. Editing DNA Methylation in the Mammalian Genome. Cell 2016, 167, 233-247. [CrossRef] [PubMed]

152. Weintraub, K. Take two: Combining immunotherapy with epigenetic drugs to tackle cancer. Nat. Med. 2016, 22, 8-10. [CrossRef] [PubMed]

(c) 2017 by the authors; licensee MDPI, Basel, Switzerland. This article is an open access article distributed under the terms and conditions of the Creative Commons Attribution (CC-BY) license (http://creativecommons.org/licenses/by/4.0/). 